\title{
The performance effects of board heterogeneity: What works for EU banks? ${ }^{1}$
}

\author{
F. Arnaboldi, B. Casu, E. Kalotychou, and A. Sarkisyan ${ }^{2}$
}

\begin{abstract}
We examine the impact of board heterogeneity on the performance of EU listed banks in the wake of the global financial crisis. In a comprehensive set-up, we consider standard board features (type, tenure, size, and age of board members) as well as board diversity features (gender diversity, employee representation, internationalisation, and age diversity). We propose a diversity index, which summarises the different dimensions of diversity, and control for unobserved heterogeneity and reverse causality. Our analysis uncovers a complex relationship between board heterogeneity and bank performance, which is influenced by market conditions and by national culture. Overall board diversity does not seem to affect bank performance, but it does decrease performance variability during the Eurozone crisis and in countries culturally more open to diversity. Different board and diversity features have a positive impact on bank performance (size, tenure, and employee representation); the relationship is non-linear, with the effect of diversity being more relevant when there is a significant proportion of minority representatives. While substantial board internationalisation has a negative impact on bank performance, the presence of foreign directors appears to be less detrimental during the Eurozone crisis and in countries that are more welcoming towards diversity.
\end{abstract}

JEL classifications: G21, G30

Keywords: corporate governance, board composition, board diversity, bank performance

\footnotetext{
${ }^{1}$ We thank Chris Adcock (the Editor), and two anonymous referees whose comments substantially improved this paper. We are also grateful to Jerry Coakley, Claudia Girardone, and Neil Kellard (the Guest Editors). This work forms part of an ongoing research project on "Governance, risk and performance in European banking". The authors gratefully acknowledge financial support from Cass Business School, City University London Pump Priming Scheme. The paper has benefited from comments at the EFiC 2017 conference at the University of Essex, ADEIMF 2017 conference at the University of Roma Tre, FINEST $5^{\text {th }}$ Anniversary conference at LUM University, and British Accounting and Finance Association conference 2018 at Central Hall Westminister, London.

${ }^{2}$ F. Arnaboldi, corresponding author: Università degli Studi di Milano, Dipartimento di Scienze Giuridiche, Cass Business School, City, University of London and CEFIN, Università degli Studi di Modena e Reggio Emilia, email: farnaboldi@unimi.it; B. Casu, Cass Business School, City, University of London, email: b.casu@city.ac.uk; E. Kalotychou, Cyprus University of Technology, email: eleni.kalotychou@cut.ac.cy, and Cass Business School, City, University of London, email: e.kalotychou@city.ac.uk; A. Sarkisyan, Essex Business School, University of Essex, email: asarkisyan@essex.ac.uk.
} 


\section{Introduction}

This paper investigates whether board heterogeneity impacts on bank performance and its variability. The global financial crisis emphasised flaws in bank corporate governance, which are thought to have played a key role in promoting and rewarding excessive risk-taking. These views prompted a discussion, both in academic and policy circles, about the role of bank corporate governance structures for financial stability. Bank governance has been at the centre of recent academic work which aimed at identifying the most effective structures (see, among others, Mehran et al., 2011; Adams and Mehran, 2012; Beltratti and Stulz, 2012). Policymakers have also responded to the perceived shortcomings of the existing governance structures with a series of initiatives, most of which included an emphasis on increased diversity. At the EU level, the crisis prompted a revision of the comprehensive corporate governance rules already in place, either in the form of directives or in the form of European regulation, to promote a culture that does not reward excessive risk-taking. ${ }^{3}$ CRD IV (an EU directive covering prudential rules for banks) incorporates changes to rules on corporate governance, including remuneration, and introduces standardised EU regulatory reporting. Among the enhanced corporate governance rules, CRD IV requirements promote diversity in board composition, although it falls short of imposing quotas. The European case is of particular interest. Many of the post-crisis governance reforms explicitly emphasise the importance of diversity in the boardroom. Most of these initiatives are based on the view that more diverse boards, with an increased presence of women and ethnic minorities, would positively affect the governance of companies. One argument is that boards could enhance their effectiveness by tapping broader talent pools for their directors. Nevertheless, evidence suggests that these affirmative actions aimed at improving the participation of women and minorities in high profile roles have had little impact. This has led several European regulators to go a step further and recommend gender quotas for publicly listed companies' boards. An often-quoted example is the Norwegian case. In 2003, the Norwegian Parliament passed a law requiring all public limited companies to have at least 40 per cent of women on their boards of directors. After voluntary compliance failed, the requirement became law in 2006, with a two-year transition period and liquidation as a penalty for non-compliance. Following Norway's example, other European countries, including Belgium, France, Italy, the Netherlands, Spain, and Germany, have since promoted legislation aiming to increase gender diversity on corporate boards via the imposition of quotas. In 2012, the European Commission (EC) proposed legislation with the aim of attaining a 40 per cent participation rate for the under-represented gender in non-executive board-member positions in publicly listed companies by 2020 . However, the regulatory framework of EU member states is still very fragmented, with some countries arguing against mandatory quotas. In addition, sanctions for non-compliance with gender balance also vary substantially among EU member states.

${ }^{3}$ The 2010 European Commission Green Paper on Corporate Governance in Financial Institutions was part of an increased effort to address the problem of corporate governance. The European Banking Authority (EBA) issued a set of guidelines, including Guidelines on Internal Governance (September 2011). EBA Guidelines have since been implemented by Member States' banking supervisory authorities. In 2017, the European Securities and Markets Authority (ESMA) issued joint guidelines with EBA on the assessment of the suitability of members of the management body and key function holders. 
We exploit this heterogeneity in board diversity in EU countries to test the impact on bank performance. Our aim is to provide evidence on whether board diversity, in aggregate and along different dimensions, increases boards' monitoring ability and promotes a culture that focuses both on increased performance and decreased performance variability, our proxy for risk. While the recent focus of both academic studies and legislative efforts has been on diversity in the context of gender, in fact, diversity comes in many different forms. We therefore consider a broader range of diversity features, such as gender diversity, employee representation, internationalisation, and age diversity, and investigate the effect of each one on bank performance. In addition to examining each characteristic separately, we aggregate the diversity measures into an index to identify the overall level of board diversity. Following Li and Wahid (2017), we construct an index based on the proportion of women, employees, and international members within each board of directors as well as the extent of age variability, with the aim to capture a board overall diversity (and its changes) at the bank level. Finally, we investigate whether cultural differences at the country level explain at least part of the heterogeneity in the impact of board diversity on the performance of EU banks. In this respect, we consider a country's openness to diversity and rely on the six cultural dimensions proposed by Hofstede (1983) and Hofstede et al. (2010), that is, power distance, individualism, masculinity, uncertainty avoidance, long-term orientation, and indulgence. To summarise these cultural differences, we collect data from the 2010 extension of the original Hofstede study on how values in the workplace are influenced by culture and derive an overall index as the average value of the six Hofstede dimensions. In so doing, we build upon a stream of the literature that focuses on the links between national culture and accounting discretion for earnings management (Kanagaretnam et al., 2011) and accounting conservatism and risk-taking (Kanagaretnam et al., 2014).

More in detail, we aim to address the following research questions: (i) Do standard board characteristics (type, tenure, size, and age of board members) impact on bank performance? (ii) Does board diversity, proxied by our diversity index, impact on bank performance? (iii) Do board diversity characteristics (gender, employee representation, internationalisation, and age diversity) impact on bank performance?

To answer these questions, we collect detailed information on board characteristics of 77 publicly listed EU banks over the period 2007-2015. We focus on listed banks because of the assumption that these institutions are subject to more stringent regulatory controls and compliance requirements; it also augments data availability in terms of board composition and enhances cross-country comparability. In addition, publicly listed banks share internationally adopted accounting standards (IFRS). Finally, the recent changes to corporate governance regulation and codes of conduct affect mostly publicly listed companies, including banks. We collect data on traditional board features including, type, size, tenure, and age, and diversity features, including gender diversity, employee representation, internationalisation, and age diversity.

Establishing a causal relationship between board diversity and firm performance is challenging. The literature has documented that board characteristics are not exogenous random variables but are endogenously chosen by firms (Hermalin and Weisbach, 2003; Adams and Ferreira, 2007; Sila et al, 2016). Two sources of endogeneity are potentially likely to bias our estimates of how board diversity 
affects bank performance: omitted variable bias and reverse causality. Omitted variable bias may arise because empirical models cannot possibly capture all the determinants of bank performance. In addition, the direction of the causal relation is unclear ex-ante. Female and minority directors can self-select into a particular type of bank, either a more profitable or a less risky bank whose existing management is more aligned with their views. On the other hand, more profitable banks may choose to appoint more women and, generally, more diverse boards. In our context, the above issues would imply that current boardroom diversity is determined by past performance. To account for these possible endogeneity issues, we take the following steps. First, we address endogeneity caused by omitted variable bias by using bank-specific controls (for example, size as larger banks may have more diverse boards) and by using country fixed effects to account for unobserved country-specific characteristics that are time-invariant and may be correlated with the level of bank diversity (that is, a country's corporate culture). Second, to mitigate endogeneity caused by reverse causality we use lagged values of the regressors. Finally, we use a dynamic panel data model, namely, the two-step dynamic panel system generalised method of moments (GMM), with instruments.

The results of this analysis are both relevant for policymakers and contribute to the academic debate. They can help shed some light on the effect of group composition on board effectiveness by evaluating the likely success of governance proposals fostering greater diversity or the possible failure of initiatives where tokenism prevents minority directors from having an impact on corporate outcomes. We find evidence that standard board characteristics affect bank performance; specifically, we find that board tenure and board size have a positive impact. Secondly, overall board diversity does not seem to affect bank performance, but different diversity features have a positive impact. Specifically, the presence of employee representatives on the board has a positive impact on bank performance, whereas age diversity has a negative impact. There is evidence of non-linearity in the impact of board composition on performance. Employee representatives increase firm value, but their merit ceases to exist when reaching a high proportion over the total board members. On the risk side, diversity features seem to play a role only when there is a significant proportion of minority representatives. While substantial board internationalisation has a negative impact on bank performance, the presence of foreign directors seems to be less detrimental during the Eurozone crisis, a period when overall diversity positively affected bank performance. When controlling for a country's cultural characteristics, we find that overall board diversity decreases risk and the negative effect of board internationalisation disappears in countries more open to diversity. Our results are consistent for a range of alternative proxies for bank performance.

Our paper contributes to the literature in several ways. First, it complements the literature on the impact of corporate governance on bank performance, which mostly focuses on either profitability or risk, by examining different dimensions of bank performance. Further, it contributes to the literature on board diversity by considering different dimensions of diversity, including gender diversity, employee representation, internationalisation, and age diversity. Finally, we also extend the prior literature on corporate governance by adding a cross-country dimension whereas most existing empirical evidence is based on single country studies. 
The remainder of the paper is organised as follows. Section 2 discusses the relevant literature; Section 3 introduces the data used for the empirical analysis and our variable definitions. Section 4 delineates the research design and Section 5 presents the results of our empirical analysis. Finally, Section 6 concludes.

\section{Literature review}

The board of directors of a firm is responsible for its major strategic and financial decisions (for example, approval of mergers and acquisitions and changes in capital structure) and for ensuring that its franchise value can survive outside shocks. The literature identifies three main functions of the board: (i) the monitoring function; (ii) the advisory function; and (iii) the resource provision function (Adams et al., 2010; Oxelheim et al, 2013); and states that the ability of the board to perform the above-mentioned functions depends crucially on the complexity of the operational structure of the firm and on the conditions of the external environment.

To the extent that the board of directors plays a role, the evidence from the existing studies on the relationship between board characteristics and firm performance is mixed (Faleye et al., 2011; Adams and Mehran, 2012; Beltratti and Stulz, 2012). Among board characteristics, diversity plays a crucial role in aligning the interest of management and shareholders and a vast literature supports the hypothesis of diversity enhancing the board of directors' monitoring and advising roles (Fields and Keys, 2003; Hermalin and Weisbach, 2003). The main argument to support diversity is that a more diverse management team tends to be more creative, more innovative, and may consider a wider range of alternatives when making decisions. In addition, more diverse boards should protect minorities, guarantee differing opinions are considered, and be harder to manipulate. There appears to be a meaningful relationship between diverse boards and improved corporate financial performance, and diverse boards can help companies more effectively recruit talent and retain staff (SEC, 2010). However, diversity may also bring costs: heterogeneous boards may be less efficient; the decision-making process may be slower, and the likelihood of reaching consensus may be smaller (Carter et al., 2003; Carter et al., 2010).

A review of the earlier literature on the relationship between board composition and corporate performance is provided by Conyon and Peck (1998). Existing research has mostly focused on a single aspect of board diversity, for example, gender diversity (Adams and Ferreira, 2009; Carter et al., 2010; Adams and Funk, 2012; Mateos de Cabo et al., 2012; Bennouri et al., 2018) or the nationality of directors (Oxelheim et al., 2013). Because of the focus on gender and nationality of previous studies, one cannot make more general inferences about the influence of board diversity. The overall impact of board diversity on performance remains relatively unexplored, with a few exceptions. Hagendorff and Keasy (2012) examine the value of board diversity in the US banking industry and find evidence that it has the potential to create shareholder value in the market for corporate control. Huyghebaert and Wang (2017) investigate corporate governance mechanisms for a large sample of Chinese listed firms and provide some evidence that experienced independent directors contribute to value creation. We seek to expand the 
existing analyses by controlling for a wider range of diversity measures, including gender diversity, employee representation, internationalisation, and age diversity.

With some exceptions, most studies have excluded financial firms from their analysis due to their regulated nature. Further, the studies that have investigated the impact of board diversity on bank performance have focused mainly on the US (see, among others, Adams and Funk, 2012; Hagendorff and Keasey, 2012; Sila et al., 2016) or on a single country (for example, Berger et al., 2014). The impact of board diversity on European banks' performance has received less attention, with a few exceptions (Mateos de Cabo et al., 2012; Garcia-Meca et al., 2015; Farag and Mallin, 2017). Based on a detailed panel data set on Finnish cooperative and savings banks, Kauko (2009) analyses the impact of managers' age and education on bank efficiency and find that university graduates, particularly those with degrees in business administration or economics, have a comparative advantage in running relatively large banks. On the other hand, the analysis also indicates that managers with vocational level qualifications in business administration improve cost efficiency for small banks. King and Williams (2016) also investigate the impact of education and find that CEO educational attainment, both level and quality, matters for bank performance. Their study indicates that CEOs with MBAs outperform their peers, particularly when managing large and complex banks.

In the wake of the financial crisis, bank boards have made an increasing number of appointments from a wider range of backgrounds in terms different demographic, educational, and social backgrounds with a view of improving performance and decreasing risk-taking incentives. We argue that diversity comes in many different forms and we therefore consider a broader range of features, including gender diversity, employee representation, internationalisation, and age diversity, to evaluate the impact of both overall diversity and of each specific diversity feature on bank performance. Our starting point in this paper is to investigate the importance of board diversity for bank performance outcomes. In doing so, we provide evidence that different aspects of diversity matter for bank performance and show the contribution of each diversity feature. In addition, we posit that the impact of board diversity is influenced by a country's culture and openness to diversity.

\section{Data and variable definition}

\subsection{Data}

To examine the relationship between corporate governance and bank performance we use data on publicly listed commercial banks from EU countries over the period 2007-2015. Listed banks are subject to more stringent regulatory controls and compliance requirements and report following the internationally adopted accounting standards (IFRS), which enhances cross-country comparability. Our sample period starts in 2007, at the onset of the global financial crisis. This allows us to investigate the relationship between corporate governance and bank performance during the global financial crisis (2007-2009) and the subsequent Eurozone crisis (2010-2015). 
The dataset is compiled from several sources. First, we collect data on corporate governance features of publicly listed banks in the $28 \mathrm{EU}$ countries from BoardEx. We then match the BoardEx data with the banks' balance sheet and income statement data collected from Bankscope (now Orbis Bank) and stock market data retrieved from Datastream (now Thomson Eikon).

In constructing the sample, we exclude banks with missing total assets or board data; we further restrict the sample to banks with at least three years of observations over the sample period. This selection strategy yields a final sample of 77 publicly listed banks from $20 \mathrm{EU}$ countries over the period of 2007-2015, which covers around 50 per cent of the total assets of these countries' banking systems. ${ }^{4}$

\subsection{Variables}

The variables used in the analysis include bank performance indicators, board characteristics, bank-specific and country-specific control variables. A detailed outline of the variables follows below along with a summary table of definitions and sources in Appendix 1.

\subsubsection{Bank performance}

Following the extant literature, we use the stock market annualised daily return $(S R)$ as our measure of bank performance and its standard deviation (SDSR) as our proxy for performance variability or risk (see, among others, Beltratti and Stulz, 2012). In additional tests, we consider alternative measures of bank performance, such as the return on assets (ROA; Bennouiri et al, 2018); the net interest margin (NIM; Kanagaretnam et al., 2014), and a widely used measure of bank solvency, the z-score (LNZSCORE; Anginer et al., 2017).

\subsubsection{Board characteristics}

We collect data on the board features of banks including: (i) standard board features, that is, type, size, tenure, and age, and (ii) board diversity features, that is, gender diversity, employee representation, internationalisation, and age diversity. Below we discuss the board features used in this study in detail.

\section{Standard board features}

Our first standard board feature is board type (DBOARDTYPE); we focus on the presence of a sole (or one-tier) versus a dual (or two-tier) board system. A sole board combines both the monitoring and the advising roles, whereas those are separated in a dual board system. While a one-tier structure is thought to favour information sharing, a two-tier structure can minimise interference from large shareholders (Adams and Ferreira, 2007).

The second standard board feature is board size, measured as the logarithm of the number of members on the board (LNBOARDSIZE). Board size is another factor perceived to affect a board's ability to monitor and advise the management. On the one hand, several studies have hypothesised a negative relation between board size and firm performance (Jensen, 1993; Hermalin and Weisbach, 2003). As board size increases, boards become less effective at monitoring management because of free-riding

\footnotetext{
${ }^{4}$ See Appendix 3 for the details of the sample composition.
} 
problems amongst directors, increased decision-making time, and coordination issues. On the other hand, larger boards can potentially bring more expertise and they might also result in less extreme decisions as they have to reconcile various opinions in the decision-making process and hence lead to lower variability in firm performance (Coles et al., 2008). In the financial services industry, however, the results on the relationship between board size and performance are mixed; possible explanations refer to regulatory issues, informational asymmetries, and organisational structure (Eisenberg et al., 1998; Adams and Mehran, 2003, 2012; Boone et al., 2007; Andrés and Vallelado, 2008; Cheng 2008; Harris and Raviv, 2008; Linck et al., 2008).

Our next standard board feature of interest is board tenure, measured as the logarithm of the average board tenure length ( $L N B O A R D T E N)$. Board stability plays a role in the execution of boards' duties. Longer tenure may have a positive effect, leading to managerial stability and deeper knowledge of the bank's business model. This, in turn, could help the board carry out both the advisory and the monitoring tasks better. In addition, as longer tenure is linked to higher entrenchment, an established board should be able to counterbalance more effectively a CEO's power. However, longer tenure can also signal lower board dynamism (Schleifer and Vishny, 1997).

Finally, we include board age, measured as the logarithm of the average board members' age (LNBOARDAGE). The relationship between board age and firm performance is unclear, with the positive findings related to the use of age as a proxy for experience.

\section{Board diversity features}

\section{Gender diversity}

To examine the impact of gender diversity on bank performance, we use the ratio of the number of female directors on the board to the total number of board directors (BOARDWOM2). Despite the importance of gender diversity in the policy debate, women hold hardly any corporate board seats. Many proposals for governance reform explicitly refer to the importance of gender diversity in the boardroom, often suggesting the need for gender quotas. Most of these initiatives are based on the view that the presence of women could significantly affect the governance of companies. Arguments in favour are that boards should not exclude female talents and that women are less entrenched and more independent. However, the effect of gender diversity on performance is mixed (Adams and Ferreira, 2009; Dezso and Ross, 2011; Garcia-Meca et al., 2015). Ahern and Dittmar (2012) use the mandatory introduction of gender quotas in Norwegian listed firms as a natural experiment to analyse the impact of quota on firm valuation. The authors find a large negative impact of the mandated board changes on firm value, because younger and less experienced members enter the board, thus reducing the effectiveness of the board. On the same case, Garcia-Lara et al. (2017) find that the changes in monitoring are not primarily driven by the introduction of gender quota, but by changes in the professional characteristics of board members, such as experience and age.

\section{Employee representation}


To assess the effect of employee representation on bank performance, we use the ratio of the number of employee representatives to the total board members (BOARDEMPL2). The presence of employees on the board is controversial, with some studies claiming it is detrimental to shareholder value. Employee representation provides workers and trade unions with reliable information about a firm's strategy and profits; this should reduce conflicts in the workplace thereby minimising the risk of strikes (Adams and Ferreira, 2007). However, excessive employee representation could lead firms to operate in the employees' interest, against shareholders' interest. Seeking to maximise perks and payroll instead of stock prices, employees can become a source of agency costs.

\section{Internationalisation}

We capture board internationalisation by the ratio of foreign directors on the board to total board members (BOARDNATMIX2). A higher number of foreign directors is frequently recommended by corporate governance codes of good practice, based on the commonly held view that directors coming from different countries increase board independence and hence foster better performance. Foreign directors have weaker or no associations with senior executives and major shareholders and should therefore be less biased, particularly when evaluating existing business practices and monitoring management. The positive influence of foreign directors on firm performance is not without critics, with arguments stating that foreign directors are not involved in the creation of a firm's long-term value (Adams and Ferreira, 2012; Fahlenbrach et al., 2017).

Age diversity

Finally, we consider the impact of board age diversity on bank performance. We use the coefficient of variation for board age (CVBOARDAGE) to capture the dispersion of age within the board. Age diversity has the potential to enhance board performance, because directors of different ages will, to some extent, have different backgrounds, skills, experiences, and social networks. By increasing the age diversity of the board of directors, the board's aggregated human and social capital can be maximised (Carter et al., 2010). On the other hand, Westphal and Zajac (1995) argue that CEOs prefer to work with demographically similar board directors. Thus, CEOs who can influence the directors' nomination process will try to hire directors who are demographically similar to themselves. However, corporate boards with similar demographics can be prone to group thinking and therefore be less efficient in their monitoring function, for instance aligning their compensation to (higher) CEO compensation (Westphal and Zajac, 1995). Empirical evidence relating to this type of diversity is limited and the results are mixed. While age diversity may be beneficial, its positive influence rests on the assumption that demographically different directors will hold differing perspectives (Li and Wahid, 2017).

\section{Diversity index}

We measure the overall degree of board diversity by constructing a bank-specific board diversity index (BOARDDIVX) based on the proportion of women, employees, and foreign directors within each board of directors as well as the extent of age variability. Specifically, we first convert our four board diversity variables (BOARDWOM2, BOARDEMPL2, BOARDNATMIX2, and CVBOARDAGE) into 
discrete score variables ranging from 1 to 10 based on the decile of the sample distribution they fall into (with 1 being the bottom and 10 the top decile). The diversity index for each bank-year is computed as:

$$
B_{0 A R D D I V X}{ }_{i t}=\frac{1}{40} \sum_{j=1}^{4} D_{i t}^{j}
$$

where $D_{i t}^{j}$ is the decile for bank-year observation it on the $j^{\text {th }}$ diversity variable $(j=1,2,3,4)$. In the case where all diversity variables are zero the index is set at zero and, hence, 1/40 standardises the index within the range of $0-1$.

Our index captures the overall gender, employee representation, internationalisation, and age diversity and is inspired by Li and Wahid (2017) who develop a similar measure in the context of tenure diversity. The construction of the index meets the four criteria that have been laid out for a good diversity measure: (i) it has a zero point to represent complete homogeneity, (ii) it is positively related to diversity, (iii) it does not assume negative values, and (iv) it is bounded. In addition, our index is a suitable measure of diversity for categorical variables that are skewed in a proportion of one category (that is, gender or employee representation), as mapping onto deciles mitigates the impact of large values. ${ }^{5}$

\subsubsection{Bank-specific features}

We control for a set of bank-level characteristics that are commonly related to bank performance (Adams and Santos, 2006; Laeven and Levine, 2009; Beltratti and Stulz, 2012; Kanagaretnam et al., 2014; Garcia-Meca et al., 2015). Specifically, we include bank size measured by the natural logarithm of total assets (LNTA). We also control for the possible effect of bank growth on performance by including total asset growth (TAGA). Next, we control for asset composition using the loan to asset ratio (LOANTA); and for the quality of the loan portfolio using the loan loss provision ratio (LLPLOAN). We also control for funding sources by including the deposit and short-term funding to total assets ratio (TDTA). We account for the impact of capital on bank performance by including the capital to total assets ratio (ETA). Finally, we control for the bank operating efficiency proxied by the cost to income ratio (CI).

\subsubsection{Country-specific features}

To account for country-specific group heterogeneity we employ either country fixed effects or country-specific variables. In particular, the latter include the size of the economy of a country, measured by the natural logarithm of gross domestic product per capita (LNGDPC) (Beltratti and Stulz, 2012; Kanagaretnam et al., 2014); the concentration of the banking system, measured by the Herfindahl Hirschman Index (HHI) (Laeven and Levine, 2009; Beltratti and Stulz, 2012; Kanagaretnam et al., 2014); a proxy for a country's financial development, that is, the size of the capital markets, assessed by the natural logarithm of the country's market capitalisation ( $L N C M C)$; and, the heterogeneity of the legal systems captured by a dummy variable which takes the value of one for common law countries (Kanagaretnam et al., 2014).

\footnotetext{
${ }^{5}$ In contrast, the Blau index that could be used as an alternative measure of diversity based on the degree of heterogeneity among board members with respect to the different attributes is unsuitable for skewed categorical variables (Blau, 1977).
} 
Cultural differences may explain part of the heterogeneity in board diversity in different EU countries. For example, empirical studies focusing on firm demand for female directors underline the role of a country's socio-political beliefs and attitudes towards women, work, and families, the gender historical role in the government, public and private initiatives in increasing the possibility of individual woman's career progression (Terjesen and Singh, 2008; Terjesen et al., 2016). To account for differences in national culture in relation to a country's openness to diversity, we rely on the six cultural dimensions originally proposed by Hofstede (1983) - power distance, individualism, masculinity, uncertainty avoidance, long-term orientation, and indulgence - which have been endorsed by later studies as good indicators of the extent to which a society supports diversity (Newburry and Yakova, 2006; Chakrabarty, 2009). For instance, a society that welcomes individualism, long-term orientation, and indulgence in the form of deviations from strict social norms is associated with a greater support of diversity. In contrast, a society where masculinity, power concentration, and uncertainty avoidance prevail is considered to be less open to diversity. We collect data from Hofstede et al. (2010) and derive an overall index (HOF) as the average of the six Hofstede dimensions. ${ }^{6}$ While our index represents a snapshot of a country's cultural openness to diversity at a particular point in time (that is, at the beginning of our sample period) and cultural aspects change over time, attitudes and beliefs transform over generations and therefore the overall change in national culture is slow.

\subsection{Descriptive statistics}

Table 1 presents the descriptive statistics for the selected board, bank-specific and countryspecific characteristics over the sample period. The bank-specific controls are winsorised at the 99 per cent level of their bank-year distribution. Panel A reports data on the full 2007-2015 sample period for performance measures and on the 2007-2014 sample period for the other variables. Looking at performance and performance variability, the sample banks, on average, have a stock return of 7.1 per cent with a yearly standard deviation of 42 per cent and a return on assets of 0.4 per cent with a 3-year standard deviation of 0.5 per cent. On average, most boards have a two-tier structure and are formed by 16.3 directors who stay in charge for 5.9 years. Female directors are present in 82.1 per cent of boards, whereas employee representatives are present in 30.2 per cent and foreign directors in 65.4 per cent of boards, respectively. However, on average, boards have only 2 female directors, or 12.6 per cent of total board members, whereas employee representatives and foreign directors constitute 8 per cent and 19.8 per cent of the board, respectively. The average age of the board directors is 57.5 years, while the coefficient of variation for board age is 15 per cent. In terms of balance sheet structure, our sample banks have an average size of around 333 billion euro, of which 57.1 per cent is invested in loans; their main source of funding is deposit and short-term liabilities (65.3 per cent of total assets), while only around 6.5 per cent of their total assets is funded by equity capital. As for country-specific characteristics, most countries adopt a civil law system, their average GDP per capita amounts to around 28 thousand euro, the

\footnotetext{
${ }^{6}$ The values of our Hofstede index range from 0 to 100, with higher values indicating countries more open to diversity. For power distance, masculinity, and uncertainty avoidance, greater openness to diversity is indicated by lower values; hence we use (100 - Dimension's value) when constructing the Hofstede index.
} 
average country market capitalisation is around 1.1 trillion euro, and the average Herfindahl Hirschman Index is 7.4 per cent. Standard deviations for these variables are high, suggesting a high heterogeneity in the sample.

< Insert Table 1 about here >

In Table 1, Panel B, we test for differences in the means of board features between the topquartile and bottom-quartile performing banks, based on their average annualised stock return. The boards of the top performing banks are, on average, more diverse. They appear to have more female directors and a higher proportion of foreign directors.

Table 2 reports descriptive statistics for the board characteristics by country. We document significant cross-country heterogeneity in the boards of the sample European banks. Looking at standard board features, banks in Germany have the largest boards (22.7 members), while the smallest boards are in the Netherlands (7.9 members). The longest board tenure is observed in Hungary (11.3 years), while the shortest in Ireland (3.2 years). Banks in Hungary also have the highest average board members' age (61.3 years), whereas those in Malta have the lowest (51.9 years).

$<$ Insert Table 2 about here >

Turning to board diversity, the greatest overall diversity is observed in bank boards in Austria (diversity index of around 0.7), closely followed by those in Germany, Czech Republic, and Sweden, while banks in Hungary have the least diverse boards (diversity index of around 0.1). In terms of gender diversity, all banks in the Czech Republic, Denmark, Lithuania, and Sweden have at least one female director on the board; banks in Sweden also show the highest presence of female directors (31.6 per cent), while the lowest is observed in Hungary (around 1.1 per cent). In the Czech Republic and Denmark all bank boards have at least one employee representative on the board; however, the greatest employee representation is observed in Germany (33.9 per cent). The greatest board internationalisation is in Romania, where all banks have at least one foreign director and the highest presence of foreign directors (40 per cent); on the other hand, banks in Hungary, Lithuania, and Malta have only domestic directors. Finally, the data show the greatest age diversity in bank boards in the Netherlands (20.9 per cent) and the lowest in Malta (8.3 per cent).

The last column of Table 2 reports the value of the Hofstede index, our proxy for a country's openness to diversity. Sweden, Denmark, and the Netherlands show the greatest openness to diversity, whereas Romania, Portugal, and Poland appear to have a national culture least open to diversity.

\section{Empirical strategy}

Our main research question is whether board diversity plays a role in explaining the performance of banks. We hypothesise that board characteristics such as type, size, tenure, and age impact on bank performance. In addition, we hypothesise that greater board diversity related to gender, employee representation, internationalisation, and age of directors influences bank performance. This section 
delineates our empirical specification and considers the two potential sources of endogeneity that are of concern in empirical studies on the relationship between board features and firm performance unobserved heterogeneity and reverse causality.

\subsection{Fixed effects model}

The following baseline model is deployed as our main vehicle for empirically testing the hypothesis of whether board characteristics impact on bank performance:

$$
P_{i t}=\alpha+X_{i, t-1} \cdot \beta+Z_{i, t-1} \cdot \gamma+\eta_{i}+\varepsilon_{i t} \quad i=1,2, \ldots, N \quad t=1,2, \ldots, T
$$

where $P_{i t}$ refers to the performance measure of bank $i$ in year $t, X_{i, t-1}$ is a matrix containing the $k$ board features, $Z_{i, t-1}$ is a matrix containing the $m$ bank-specific control variables. The $(1+k+m)$ coefficient vector $(\alpha, \beta, \gamma)$ is to be estimated. The error term $u_{i t}=\eta_{i}+\varepsilon_{i t}$ is assumed to be independent from the $k$ board-specific regressors and the $m$ bank-specific controls. The noise $\varepsilon_{\mathrm{it}}$ is assumed to be identically and independently distributed, whereas the time-invariant component $\eta_{i}$ represents unobserved firm-specific heterogeneity. The model controls for time effects through a full set of yearly dummies. Country-specific group heterogeneity is accounted for by using either country fixed effects or country-specific variables. The use of fixed effects helps to mitigate biases caused by time-invariant omitted variables correlated with the regressors, which result in inconsistent parameter estimates. Country-specific effects capture the latent influence of country corporate culture that is likely to be correlated with bank board diversity. Country- as opposed to firm-level fixed effects are employed as an appropriate way to mitigate omitted variable bias while avoiding unreliable slope estimates caused by firm-specific fixed effects absorbing most of the variation across firms. The use of lagged regressors also helps to alleviate some of the endogeneity concerns. The covariance structure of the estimated coefficients is clustered at the firm level to allow for within-bank correlation over time.

In additional analyses, we investigate whether the effect of board characteristics on performance is non-linear and, in particular, whether a board diversity feature, such as the presence of foreign directors, has a disproportionately greater impact in boards where it is more prevalent. We do so by considering thresholds computed as sample averages for each board feature. ${ }^{7}$

We also examine whether the impact of the standard and diversity board features becomes stronger during the period of the Eurozone crisis through the interaction of the board characteristics with a Eurozone crisis dummy that takes the value of 1 over the crisis period.

\footnotetext{
${ }^{7}$ For instance, the average proportion of foreign directors on the board of our sampled banks over the period is 8 per cent, which is used as a threshold to consider whether the role of foreign directors is more pronounced in banks whose boards are substantially more international (i.e., the number of foreign directors exceeds the threshold).
} 
Finally, we examine whether board diversity features play a bigger role in countries that are culturally more open to diversity through the interaction of board diversity features with a Hofstede dummy that takes the value of 1 for countries with the Hofstede index value above the sample mean.

\subsection{Two-step dynamic panel generalised method of moments}

Another possible source of endogeneity when investigating the relationship between board diversity and performance is reverse causality stemming from the fact that the choice of board composition could rely on current and past realisations of performance and risk. For instance, better performing firms may have greater gender diversity. In addition to past realisations of performance and risk, the extent of board diversity is a choice that can be influenced by bank- and board-specific characteristics and unobserved factors, for example, more complex firms with bigger boards may opt for more diversity. As performance and risk are correlated over time, this induces correlation between the residuals and the regressors and thus inconsistency of the fixed effects estimator in the case of fat (short$\mathrm{T}$, large-N) panels.

Bearing in mind the aforementioned issues, the Dynamic Panel System - Generalised Method of Moments (DPS-GMM) proposed by Arellano and Bover (1995) and Blundell and Bond (1998) lends itself naturally as the appropriate empirical framework to estimate the relationship between board diversity and performance. The intuition is that in order to determine their board composition, banks rely on past performance as well as other board and bank characteristics. As the information set underlying the decisions is not correlated with the unexpected error term, these variables can be used as instruments for board appointment decisions. The model augments that in equation (1) as follows:

$$
P_{i t}=\alpha+X_{i, t-1} \cdot \beta+Z_{i, t-1} \cdot \gamma+\sum_{j=1}^{q} \delta_{j} P_{i t-j}+\eta_{i}+\varepsilon_{i t}
$$

where $q=1$ in our analysis. We deploy a two-step estimation approach using as instruments the lag of all independent variables and include yearly time effects. The reported t-statistics are based on Windmeijer's (2005) corrected standard errors that are robust in the presence of uncertainty stemming from two-step estimation for small panels.

Given the challenges in identifying a unique truly exogenous instrument, our identification relies on the fact that all factors affecting board composition are either included in the board characteristics or in past values of performance and risk. We compute the Arellano-Bond (1991) test for no autocorrelation in the differenced residual series. Autocorrelation indicates that lags of the dependent variable (and any other not strictly exogenous variables used as instruments) are endogenous, thus bad instruments. The second order autocorrelation is the one of relevance as presence of first order dependence in the residual first difference $\left(\Delta \varepsilon_{i t}\right)$ is guaranteed by definition through the common term $\varepsilon_{i t-1}$. Finally, the joint validity of the instruments is assessed by using the Hansen and Singleton (1982) test. 


\section{Empirical results}

The main aim of our analysis is to examine the link between board characteristics and bank performance and performance variability. In our first model specification we address our first research question and examine whether standard board characteristics impact on bank performance. To do so we regress the relevant bank performance measure on the type of board, board tenure, board size, and average age of board members. Moving to our second research question, we investigate whether board diversity impacts on bank performance by augmenting the model with our diversity index. In our third model specification, we decompose the index into its constituent board diversity dimensions (gender diversity, employee representation, internationalisation, and age diversity) and look at their individual impact on bank performance to answer to our third research question.

\subsection{Effects of board characteristics on bank performance}

The regression results of the models in Equation (1) that investigate the impact of standard board features and board diversity on bank performance and performance variability are shown in Table 3. In column (1), we examine the effect of standard board features on annualised stock returns $(S R)$ and their standard deviation (SDSR), in columns (2)-(3) we add the diversity index, and in column (4) we replace the index with the individual board diversity variables. All specifications use bank-specific control variables and account for time- and country-specific fixed effects. The model in column (3) does so using country control variables rather than fixed effects. The results are qualitatively similar; therefore, we conduct the rest of the analysis using country fixed effects. The estimated coefficients on the bank and country control variables exhibit the expected signs. ${ }^{8}$

\section{< Insert Table 3 about here >}

We find that among the standard board features the size of the board (LNBOARDSIZE) is positively associated with $S R$, suggesting that larger boards improve bank performance. This finding is in line with the strand of the literature that promotes the view that larger boards can potentially bring more experience and knowledge and hence offer better advice, particularly for larger and more complex firms such as banks (Coles et al., 2008). In addition, board size does not seem to impact on performance variability. Board tenure (LNBOARDTEN), on the other hand, while not impacting upon bank performance, seems to have a positive effect on performance variability, which is significant in our specification with country-specific controls, indicating the benefit of board stability for managerial effectiveness. This result is in line with the literature that posits that the tenure of board members affects their level of firm-specific knowledge and expertise and that time on the job improves board effectiveness (Celikyurt et al., 2014).

Turning to board diversity, the results show that the overall diversity of the board, as measured by the diversity index, is not related to bank performance. However, looking at the component board

\footnotetext{
${ }^{8}$ Correlations between the variables used in the analysis are reported in Appendix 2.
} 
diversity features, we find that the presence of employee representatives (BOARDEMPL2) reduces bank risk, which is consistent with the view that it may allow boards' preferences to be more aligned with those of managers (Adams and Ferreira, 2007). On the other hand, the presence of foreign directors (BOARDNATMIX2) increases bank risk. While there has been a "pro-internationalisation shift" in board composition in recent years, the empirical evidence is mixed. The positive influence view of foreign directors is not shared by all, with arguments stating that foreign directors are less involved in the creation of a firm's long-term value; other critics claim that their understanding of the firm's business might be limited and their contribution might be negligible at best or negative. Adams and Ferreira (2012) document that outside directors have more attendance problems at bank board meetings and find evidence of free-riding. Fahlenbrach et al. (2014) document a dark side of outside directors and find evidence to suggest that they have incentives to resign to protect their reputation or to avoid an increase in their workload when they anticipate that the firm will perform poorly or disclose adverse news. Our results so far seem to provide support for a less positive contribution of the presence of foreign directors on bank boards. Finally, we find that gender diversity does not impact either bank risk or performance. ${ }^{9}$

However, it could be argued that the impact of board features on bank performance might be nonlinear. The literature has uncovered a U-shaped relationship between board size and performance and between the proportion of non-executive directors and performance. De Andres and Vallelado (2008) show that larger and not excessively independent boards create more value; however, this relationship is non-monotonic and when the board reaches a certain size, firm value decreases. Similarly, they find that outside directors increase firm value, in line with board size, but destroy value when reaching a higher proportion over the total board members. Huang and Hilary (2017) uncover a U-shaped relationship between board tenure and firm value and accounting performance, which is consistent with the interpretation that directors' on-the-job learning improves firm value up to a threshold, at which point entrenchment dominates and firm performance suffers.

We argue that diversity may become relevant only when minority voices reach a certain threshold and its impact becomes bigger when the proportion of minority representatives becomes more prevalent. For instance, the voice of women might become more effective in boards where the gender diversity is already significant. We explore the presence of this type of non-linearity through the use of thresholds for the board features, which implies differential effects when the relevant board variable is above or below a certain level. Table 4 reports the estimation results, where a suffix $U P$ or $D N$ added to a board variable indicates the interaction between the board variable and a dummy for its value above or below the sample mean, respectively. As before, in Model (1) we use thresholds for the standard board features only and control for bank-specific variables; in Models (2)-(3) we use thresholds for the diversity board features while controlling for the standard board features and bank-specific variables.

< Insert Table 4 about here >

${ }^{9}$ To ensure that our findings are not driven by the performance of Italian banks, we re-run the analysis without Italian banks in the sample and the results are broadly consistent. 
The results show that the estimated performance benefit incurred by larger boards is non-linear and only documented when the board size is bigger than average, with the above the threshold board size variable (LNBOARDSIZEUP) showing a positive and statistically significant association with stock returns. Looking at the board diversity, the results show non-linearity in the impact of employee representation on bank performance. In particular, we find that the positive contribution of employee representatives reaches a cap, as it becomes insignificant after the proportion of employees exceeds the threshold. On the risk side, we also find that the estimated positive effect of employee representation holds only when the presence of employee representatives on the board is higher than average (significance of BOARDEMPL2UP). Interestingly, we find similar non-linearity in the estimated risk effect of board internationalisation, where the latter impacts on risk only when the proportion of foreign directors on the board is relatively large (significance of BOARDNATMIX2UP). This negative effect is consistent with the evidence of De Andres and Vallelado (2008) that show that, when reaching a high proportion over the total board, outside directors decrease firm value.

We next examine the impact of the Eurozone crisis on the relationship between board features and bank performance. The estimation results are reported in Table 5. In Model (1) we include our standard board features and their interactions with the Eurozone crisis dummy (the latter is equal to 1 for years 2010-2014 and zero for years 2007-2009) and control for bank-specific characteristics; in Models (2)-(3) we examine our board diversity features and their interactions with the Eurozone crisis dummy, while controlling for the standard board features and bank-specific characteristics.

$<$ Insert Table 5 about here >

The key finding that emerges from the Eurozone crisis analysis is that board diversity reduces variability in performance during the crisis period. In particular, the results of Model (2) suggest that the overall board diversity reduced bank risk during the Eurozone crisis (ECBOARDDIVX is negatively associated with SDSR). The results of Model (3) further suggest that the risk-reducing effect of board diversity during the Eurozone crisis is mainly driven by the change in the effect of board internationalisation (ECBOARDNATMIX2 is negatively associated with SDSR), which becomes less aggravating. As far as standard board features are concerned, older than average boards seem to increase bank performance variability during the Eurozone crisis, as indicated by the results of Model (1) which show a positive association between ECBOARDAGE and SDSR.

Finally, we examine whether a country's national culture with respect to openness to diversity has an impact on the association between board diversity features and bank performance. Table 6 reports the estimation results. In Model (1) we include the diversity index and its interaction with the Hofstede dummy (the latter is equal to 1 for countries more open to diversity and zero otherwise) while controlling for the standard board features and other bank-specific characteristics; in Model (2) we examine the component diversity features and their interactions with the Hofstede dummy, while controlling for the standard board features and bank-specific characteristics.

$<$ Insert Table 6 about here > 
The results of Model (1) suggest that the overall diversity of the board reduces bank risk in countries that are culturally more open to diversity. Specifically, the adverse effect of board diversity on performance variability (SDSR) disappears in countries that are culturally open to diversity as indicated by the negative and significant Hofstede interaction term (HOFBOARDDIVX). This seems to be driven by the distinct impact foreign directors have in the two groups of countries: significantly increasing risk in countries less open to diversity, while having virtually no impact in countries more open to diversity, as suggested by the estimated coefficients of BOARDNATMIX2 and HOFBOARDNATMIX2.

Summarising, the results so far suggest that board size and diversity in the form of employee representation have a positive impact on bank performance, while board internationalisation increases bank risk. The proportion of employee representatives on the board plays a positive role for bank performance up to a threshold level, beyond which there is no incremental value added. On the other hand, diversity impacts risk only when minority proportions become substantial. In particular, presence of a large proportion of employee representatives decreases risk, while a high number of foreign directors seems to have the opposite effect. Further, the results indicate that board diversity decreased performance variability during the Eurozone crisis due to the less negative effect of foreign directors during that period. On the other hand, board age had an increasing effect on bank risk during the Eurozone crisis. Overall, the results suggest that the national cultures that welcome diversity improve the impact of board diversity on bank performance.

\subsection{Robustness tests}

We carry out additional analyses to examine the robustness of our results to alternative measures of bank performance and performance variability as well as to alternative estimation frameworks that treat the potential endogeneity issues emanating from reverse causality between board composition and bank performance.

\subsubsection{Alternative performance measures}

We test whether the results discussed in the previous section hold for alternative measures of bank performance. Specifically, we use the accounting-based return on assets (ROA) and net interest margin (NIM) to measure bank performance and the standard deviation of return on assets (SDROA) and the standard deviation of the net interest margin (SDNIM) to measure bank risk. ${ }^{10}$ Finally, we use a distance to default measure, the z-score (LNZSCORE), which combines performance and risk by estimating the number of standard deviations that a bank's profits have to fall below its expected value before its equity becomes negative. The results are reported in Table 7.

$<$ Insert Table 7 about here >

We find that board tenure is negatively associated with SDROA and positively associated with LNZSCORE. This shows that our finding of a risk-reducing effect of board tenure holds for the alternative

\footnotetext{
${ }^{10}$ We drop LLPLOAN from NIM and SDNIM regressions due to high correlation between the variables.
} 
risk measures. Looking at the board diversity features, we find that BOARDEMPL2 is associated positively with $R O A$ and negatively with SDNIM. Overall, this confirms our finding of the performanceimproving effect of employee representation on the board.

\subsubsection{Endogeneity}

We attempt to address possible endogeneity concerns in the estimation of the impact of board characteristics on bank performance by employing a two-step DPS-GMM estimation framework (Equation (2)). We conduct the analysis for our main performance measures (that is, $S R$ and $S D S R$ ) and additional performance measures (that is, ROA, SDROA, NIM, SDNIM, and LNZSCORE).

Table 8 reports the estimation results for $S R$ and SDSR. Overall, we find evidence consistent with our main findings. In particular, the GMM results confirm the risk-reducing effect of board tenure and the risk-increasing effect of board age. Further, we find supportive evidence that, while the overall diversity of the board captured by the diversity index, is not related to bank performance, employee representation on the board has a risk-reducing impact.

$<$ Insert Table 8 about here >

Lastly, Table 9 reports the results of the GMM estimation for our alternative performance measures. Overall, the evidence confirms our findings, including the risk-reducing impact of board tenure ( LNBOARDTEN is negatively associated with SDROA and SDNIM).

< Insert Table 9 about here >

\section{Conclusions}

In this paper, we document the impact of board heterogeneity on the performance of EU listed banks in the years following the global financial crisis, a period of turbulence for European banks. In a comprehensive set-up, we consider a variety of board characteristics, including standard board features (type, tenure, size, and age of board members) and board diversity features (gender diversity, employee representation, internationalisation, and age diversity). In addition, we propose a diversity index, which summarises the different dimensions of diversity. In our empirical analysis, we control for unobserved heterogeneity and reverse causality.

We find that board size has a positive impact on bank performance and this impact is mostly relevant for larger boards. This result provides support to the stream of literature that posits that larger and potentially more diverse boards can offer a wider range of expertise and therefore offer better advice, particularly for larger and more complex firms such as banks. Board tenure also has a positive impact on bank performance. This suggest that time on the job improves board effectiveness; and for bank boards to be effective at monitoring management, the tenure of board members is particularly relevant as it affects their level of firm-specific knowledge and expertise. This result seems to contrast with the view that 
boards with long-serving members are entrenched and therefore there should be specific term limits on directors' service.

Our findings on the role of board diversity indicate that the presence of employee representatives improves bank performance and reduces performance variability, while substantial presence of foreign directors increases bank risk. The results reveal no impact of gender diversity on bank performance. Further analysis uncovers a non-linear relationship between diversity and bank performance. Board diversity plays a bigger role in banks whose boards comprise a higher than average proportion of minority representatives. In addition, the positive impact of employee representatives is capped at a certain level of employee proportion.

We also find that overall board diversity decreased performance variability during the Eurozone crisis, particularly due to the less detrimental impact of foreign directors which might go to suggest that boards with a more diverse set of skills and experiences can be more effective during times of financial turbulence. On the other hand, board age had a positive effect on bank risk during the crisis.

Interestingly, our results also suggest that differences in national culture across EU countries could be one of the reasons behind the differential impact of board diversity on bank performance. Board diversity reduces risk in countries culturally more welcoming to diversity, while the opposite is true for countries less open to diversity. Finally, our results are consistent for a wide range of alternative proxies for bank performance and the treatment of endogeneity.

Our evidence therefore supports recent policy initiatives aiming to foster board diversity. However, the impact of minority directors on bank performance is constrained by their representativeness on the board and influenced by the cultural norms in the country where the bank is headquartered. 
Table 1 Descriptive statistics

\begin{tabular}{|c|c|c|c|c|c|}
\hline \multicolumn{6}{|c|}{ Panel A: Full sample } \\
\hline & No. of Obs. & Mean & Std. Dev. & Min & Max \\
\hline \multicolumn{6}{|c|}{ Performance measures } \\
\hline$S R$ & 684 & 0.071 & 0.795 & -3.750 & 9.443 \\
\hline$S D D S R$ & 684 & 0.420 & 0.275 & 0.011 & 3.202 \\
\hline$R O A$ & 672 & 0.004 & 0.013 & -0.124 & 0.044 \\
\hline SDROA & 675 & 0.005 & 0.009 & 0.000 & 0.081 \\
\hline NIM & 678 & 0.021 & 0.023 & -0.474 & 0.122 \\
\hline SDNIM & 679 & 0.003 & 0.010 & 0.000 & 0.247 \\
\hline ZSCORE & 670 & 55.543 & 78.224 & -2.434 & 725.143 \\
\hline \multicolumn{6}{|c|}{ Board structure variables } \\
\hline DBOARDTYPE & 563 & 0.933 & 0.251 & 0.000 & 1.000 \\
\hline BOARDSIZE & 563 & 16.298 & 5.927 & 6.000 & 34.000 \\
\hline BOARDTEN & 561 & 5.901 & 2.742 & 0.100 & 16.300 \\
\hline$B O A R D A G E$ & 563 & 57.463 & 4.439 & 35.800 & 69.500 \\
\hline BOARDDIVX & 563 & 0.467 & 0.173 & 0.100 & 0.875 \\
\hline DBOARDWOM & 563 & 0.821 & 0.384 & 0.000 & 1.000 \\
\hline BOARDWOM & 563 & 1.996 & 1.748 & 0.000 & 8.000 \\
\hline BOARDWOM2 & 563 & 0.126 & 0.107 & 0.000 & 0.600 \\
\hline DBOARDEMPL & 563 & 0.302 & 0.460 & 0.000 & 1.000 \\
\hline BOARDEMPL & 563 & 1.474 & 2.762 & 0.000 & 14.000 \\
\hline BOARDEMPL2 & 563 & 0.080 & 0.133 & 0.000 & 0.600 \\
\hline DBOARDNATMIX & 540 & 0.654 & 0.476 & 0.000 & 1.000 \\
\hline BOARDNATMIX2 & 540 & 0.198 & 0.197 & 0.000 & 0.800 \\
\hline CVBOARDAGE & 563 & 0.150 & 0.049 & 0.013 & 0.905 \\
\hline \multicolumn{6}{|c|}{ Bank-specific variables } \\
\hline$T A B L$ & 563 & 332.973 & 528.288 & 0.628 & $2,150.486$ \\
\hline$T A G A$ & 563 & 0.063 & 0.163 & -0.272 & 0.889 \\
\hline LOANTA & 563 & 0.571 & 0.194 & 0.065 & 0.848 \\
\hline$T D T A$ & 563 & 0.653 & 0.155 & 0.238 & 0.935 \\
\hline ETA & 563 & 0.065 & 0.033 & -0.002 & 0.164 \\
\hline LLPLOAN & 552 & 0.011 & 0.011 & -0.001 & 0.064 \\
\hline$C I$ & 559 & 0.611 & 0.161 & 0.342 & 1.487 \\
\hline \multicolumn{6}{|c|}{ Country-specific variables } \\
\hline$L E G A L$ & 563 & 0.146 & 0.353 & 0 & 1 \\
\hline$C M C$ & 549 & $1,112,874$ & 961,050 & $1,870.49$ & $3,296,011$ \\
\hline$G D P P C$ & 563 & 27,955 & 9,927 & 5,900 & 46,200 \\
\hline \multirow[t]{2}{*}{$H H I$} & 563 & 0.074 & 0.042 & 0.0183 & 0.2195 \\
\hline & & & & \multicolumn{2}{|c|}{ Continued on next page } \\
\hline
\end{tabular}


Table 1 (continued)

\begin{tabular}{|c|c|c|c|c|c|}
\hline \multicolumn{6}{|c|}{ Panel B: Test for differences in board characteristics of top and bottom performing banks } \\
\hline & No. of Obs. & Mean & No. of Obs. & Mean & Mean Differential \\
\hline & \multicolumn{2}{|c|}{ Top quartile } & \multicolumn{2}{|c|}{ Bottom quartile } & \\
\hline \multicolumn{6}{|c|}{ Board structure variables } \\
\hline DBOARDTYPE & 140 & 0.950 & 142 & 0.937 & 0.013 \\
\hline BOARDSIZE & 140 & 15.671 & 142 & 16.275 & -0.603 \\
\hline BOARDTEN & 140 & 5.756 & 141 & 5.530 & 0.227 \\
\hline$B O A R D A G E$ & 140 & 56.973 & 142 & 57.618 & -0.645 \\
\hline BOARDDIVX & 140 & 0.486 & 142 & 0.431 & $0.556^{* *}$ \\
\hline$D B O A R D W O M$ & 140 & 0.879 & 142 & 0.761 & $0.118 * *$ \\
\hline BOARDWOM & 140 & 2.007 & 142 & 1.683 & $0.324 *$ \\
\hline BOARDWOM2 & 140 & 0.130 & 142 & 0.104 & $0.025 * *$ \\
\hline DBOARDEMPL & 140 & 0.300 & 142 & 0.211 & $0.088 *$ \\
\hline BOARDEMPL & 140 & 1.457 & 142 & 1.190 & 0.267 \\
\hline BOARDEMPL2 & 140 & 0.079 & 142 & 0.059 & 0.020 \\
\hline DBOARDNATMIX & 136 & 0.713 & 136 & 0.581 & $0.132 * *$ \\
\hline BOARDNATMIX2 & 136 & 0.216 & 136 & 0.173 & $0.043^{*}$ \\
\hline CVBOARDAGE & 140 & 0.152 & 142 & 0.156 & -0.005 \\
\hline
\end{tabular}

The table reports descriptive statistics for the sample. Panel A reports the summary statistics for performance measures used as dependent variables (over 2007-2015) and for board structure, bank- and country-specific variables used as lagged explanatory variables (over 2007-2014); bank-specific characteristics are winsorised at $99 \%$ of the bank-year distribution. Panel B reports the comparison between the board structure variables for banks in the top and bottom quartiles of stock return (SR) in each year of the sample. The t-test for the equality of means is reported in the last column. *, ** indicate significance at the $5 \%$ and $10 \%$ level, respectively. Definitions of the variables are provided in Appendix 1. 
Table 2 Board characteristics by country

\begin{tabular}{|c|c|c|c|c|c|c|c|c|c|c|c|c|c|}
\hline Country & DBOARDTYPE & BOARDSIZE & BOARDTEN & BOARDAGE & BOARDDIVX & DBOARDWOM & BOARDWOM 2 & DBOARDEMPL & BOARDEMPL2 & DBOARDNATMIX & BOARDNATMIX2 & CVBOARDAGE & $\mathrm{HOF}$ \\
\hline \multirow[t]{2}{*}{ Austria } & 1.000 & 20.400 & 7.418 & 56.825 & 0.682 & 0.925 & 0.118 & 0.925 & 0.295 & 0.846 & 0.290 & 0.169 & 53 \\
\hline & $(0.000)$ & (3.507) & (1.945) & $(2.368)$ & $(0.143)$ & $(0.267)$ & $(0.083)$ & $(0.267)$ & $(0.101)$ & $(0.366)$ & $(0.23)$ & $(0.022)$ & \\
\hline \multirow[t]{2}{*}{ Belgium } & 1.000 & 17.250 & 4.084 & 56.310 & 0.431 & 0.850 & 0.100 & 0.000 & 0.000 & 0.800 & 0.290 & 0.144 & 50 \\
\hline & $(0.000)$ & $(6.315)$ & (1.976) & (3.037) & $(0.167)$ & $(0.366)$ & $(0.074)$ & $(0.000)$ & $(0.000)$ & $(0.410)$ & $(0.177)$ & $(0.035)$ & \\
\hline \multirow[t]{2}{*}{ Cyprus } & 0.842 & 15.211 & 4.463 & 56.263 & 0.397 & 0.789 & 0.100 & 0.158 & 0.029 & 0.474 & 0.121 & 0.155 & $\mathrm{n} / \mathrm{a}$ \\
\hline & $(0.375)$ & $(4.022)$ & (2.539) & $(5.063)$ & $(0.125)$ & $(0.419)$ & $(0.091)$ & $(0.375)$ & $(0.074)$ & $(0.513)$ & $(0.151)$ & $(0.045)$ & \\
\hline \multirow[t]{2}{*}{ Czech R. } & 1.000 & 14.500 & 5.538 & 54.362 & 0.650 & 1.000 & 0.069 & 1.000 & 0.232 & 0.875 & 0.363 & 0.162 & 45 \\
\hline & $(0.000)$ & $(0.756)$ & $(0.571)$ & (1.424) & $(0.071)$ & $(0.000)$ & $(0.004)$ & $(0.000)$ & $(0.047)$ & $(0.354)$ & $(0.292)$ & $(0.011)$ & \\
\hline \multirow[t]{2}{*}{ Denmark } & 0.750 & 13.750 & 7.528 & 54.909 & 0.571 & 1.000 & 0.176 & 1.000 & 0.289 & 0.350 & 0.155 & 0.137 & 70 \\
\hline & $(0.44)$ & (3.802) & (1.599) & (1.832) & $(0.123)$ & $(0.000)$ & $(0.069)$ & $(0.000)$ & $(0.085)$ & $(0.489)$ & $(0.250)$ & $(0.032)$ & \\
\hline \multirow[t]{2}{*}{ France } & 0.850 & 17.825 & 5.345 & 58.432 & 0.541 & 0.825 & 0.192 & 0.875 & 0.145 & 0.650 & 0.113 & 0.146 & 48 \\
\hline & $(0.362)$ & (5.310) & (1.292) & $(4.181)$ & $(0.168)$ & $(0.385)$ & $(0.137)$ & $(0.335)$ & $(0.088)$ & $(0.483)$ & $(0.111)$ & $(0.127)$ & \\
\hline \multirow[t]{2}{*}{ Germany } & 1.000 & 22.719 & 4.659 & 52.603 & 0.646 & 0.844 & 0.158 & 0.969 & 0.339 & 0.688 & 0.159 & 0.146 & 54 \\
\hline & $(0.000)$ & (8.368) & (1.093) & (2.994) & $(0.162)$ & (0.369) & $(0.090)$ & $(0.177)$ & (0.104) & $(0.471)$ & $(0.181)$ & $(0.042)$ & \\
\hline \multirow[t]{2}{*}{ Greece } & 1.000 & 15.591 & 7.386 & 59.659 & 0.366 & 0.909 & 0.084 & 0.000 & 0.000 & 0.364 & 0.068 & 0.168 & 36 \\
\hline & $(0.000)$ & (2.423) & $(2.021)$ & (4.137) & $(0.106)$ & $(0.294)$ & $(0.039)$ & $(0.000)$ & $(0.000)$ & $(0.492)$ & $(0.125)$ & $(0.047)$ & \\
\hline \multirow{2}{*}{ Hungary } & 1.000 & 10.250 & 11.288 & 61.325 & 0.128 & 0.125 & 0.011 & 0.000 & 0.000 & 0.000 & 0.000 & 0.100 & 42 \\
\hline & $(0.000)$ & $(1.035)$ & (1.391) & $(1.524)$ & $(0.041)$ & $(0.354)$ & $(0.032)$ & $(0.000)$ & $(0.000)$ & $(0.000)$ & $(0.000)$ & $(0.007)$ & \\
\hline \multirow[t]{2}{*}{ Ireland } & 1.000 & 12.375 & 3.231 & 57.713 & 0.420 & 0.875 & 0.106 & 0.000 & 0.000 & 0.938 & 0.238 & 0.137 & 55 \\
\hline & $(0.000)$ & (2.473) & (1.198) & (1.485) & $(0.080)$ & $(0.342)$ & $(0.057)$ & $(0.000)$ & $(0.000)$ & $(0.250)$ & $(0.102)$ & $(0.023)$ & \\
\hline \multirow[t]{2}{*}{ Italy } & 0.979 & 18.990 & 5.179 & 61.308 & 0.333 & 0.639 & 0.070 & 0.000 & 0.000 & 0.356 & 0.070 & 0.160 & 45 \\
\hline & $(0.143)$ & $(7.051)$ & $(2.542)$ & (3.755) & $(0.111)$ & $(0.483)$ & $(0.081)$ & $(0.000)$ & $(0.000)$ & $(0.481)$ & $(0.108)$ & $(0.031)$ & \\
\hline \multirow[t]{2}{*}{ Lithuania } & 1.000 & 14.667 & 5.200 & 52.033 & 0.408 & 1.000 & 0.227 & 0.000 & 0.000 & 0.000 & 0.000 & 0.153 & 55 \\
\hline & $(0.000)$ & $(0.577)$ & $(0.700)$ & (1.528) & (0.029) & $(0.000)$ & $(0.035)$ & $(0.000)$ & $(0.000)$ & $(0.000)$ & $(0.000)$ & $(0.023)$ & \\
\hline \multirow[t]{2}{*}{ Malta } & 0.000 & 9.000 & 7.533 & 51.900 & 0.200 & 0.333 & 0.037 & 0.000 & 0.000 & 0.000 & 0.000 & 0.083 & 45 \\
\hline & $(0.000)$ & $(0.000)$ & (1.401) & (1.418) & $(0.100)$ & $(0.577)$ & (0.064) & $(0.000)$ & $(0.000)$ & $(0.000)$ & $(0.000)$ & $(0.096)$ & \\
\hline \multirow[t]{2}{*}{ Netherlands } & 1.000 & 7.875 & 4.650 & 53.925 & 0.350 & 0.125 & 0.028 & 0.000 & 0.000 & 0.125 & 0.025 & 0.209 & 68 \\
\hline & $(0.000)$ & $(0.641)$ & (1.702) & $(2.836)$ & $(0.093)$ & $(0.354)$ & $(0.079)$ & $(0.000)$ & $(0.000)$ & $(0.354)$ & $(0.071)$ & $(0.027)$ & \\
\hline \multirow[t]{2}{*}{ Poland } & 1.000 & 16.786 & 4.919 & 52.214 & 0.468 & 0.810 & 0.107 & 0.000 & 0.000 & 0.667 & 0.374 & 0.156 & 34 \\
\hline & $(0.000)$ & (1.718) & (1.862) & $(4.39)$ & $(0.132)$ & $(0.397)$ & $(0.080)$ & $(0.000)$ & $(0.000)$ & $(0.477)$ & $(0.279)$ & $(0.024)$ & \\
\hline \multirow[t]{2}{*}{ Portugal } & 0.967 & 19.767 & 7.227 & 57.707 & 0.377 & 0.633 & 0.033 & 0.000 & 0.000 & 0.767 & 0.210 & 0.157 & 33 \\
\hline & $(0.183)$ & (6.986) & $(4.085)$ & (2.096) & $(0.107)$ & $(0.490)$ & $(0.030)$ & $(0.000)$ & $(0.000)$ & $(0.430)$ & $(0.130)$ & $(0.028)$ & \\
\hline \multirow[t]{2}{*}{ Romania } & 1.000 & 9.857 & 6.229 & 59.800 & 0.389 & 0.857 & 0.087 & 0.000 & 0.000 & 1.000 & 0.400 & 0.109 & 30 \\
\hline & $(0.000)$ & $(0.378)$ & $(0.757)$ & (1.143) & $(0.056)$ & $(0.378)$ & $(0.039)$ & $(0.000)$ & $(0.000)$ & $(0.000)$ & $(0.129)$ & $(0.010)$ & \\
\hline \multirow[t]{2}{*}{ Spain } & 1.000 & 14.159 & 8.375 & 60.995 & 0.387 & 0.955 & 0.128 & 0.000 & 0.000 & 0.750 & 0.134 & 0.139 & 43 \\
\hline & $(0.000)$ & (3.206) & (3.773) & (3.907) & $(0.101)$ & $(0.211)$ & $(0.063)$ & $(0.000)$ & $(0.000)$ & $(0.438)$ & $(0.094)$ & $(0.035)$ & \\
\hline \multirow[t]{2}{*}{ Sweden } & 0.625 & 11.225 & 6.333 & 54.687 & 0.640 & 1.000 & 0.316 & 0.600 & 0.125 & 0.974 & 0.316 & 0.137 & 73 \\
\hline & $(0.490)$ & (2.224) & $(2.021)$ & (3.191) & $(0.108)$ & $(0.000)$ & $(0.122)$ & $(0.496)$ & $(0.113)$ & $(0.162)$ & $(0.155)$ & $(0.040)$ & \\
\hline \multirow[t]{2}{*}{ UK } & 1.000 & 13.308 & 4.560 & 58.463 & 0.473 & 0.962 & 0.151 & 0.000 & 0.000 & 0.942 & 0.338 & 0.139 & 62 \\
\hline & $(0.000)$ & $(3.467)$ & $(2.262)$ & $(1.627)$ & $(0.089)$ & $(0.194)$ & $(0.076)$ & $(0.000)$ & $(0.000)$ & $(0.235)$ & $(0.136)$ & $(0.045)$ & \\
\hline
\end{tabular}

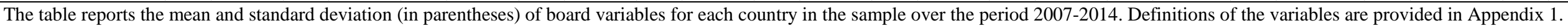


Table 3 Do board characteristics impact on bank performance?

\begin{tabular}{|c|c|c|c|c|c|c|c|c|}
\hline & \multicolumn{4}{|c|}{$S R$} & \multicolumn{4}{|c|}{ SDSR } \\
\hline & Model (1) & Model (2) & Model (3) & Model (4) & Model (1) & Model (2) & Model (3) & Model (4) \\
\hline \multirow[t]{2}{*}{ DBOARDTYPE } & 0.0305 & 0.0342 & 0.0086 & 0.1065 & -0.0207 & -0.0205 & $0.0862 * *$ & -0.0253 \\
\hline & $(0.29)$ & $(0.34)$ & $(0.13)$ & $(0.83)$ & $(-0.47)$ & $(-0.47)$ & $(2.46)$ & $(-0.54)$ \\
\hline \multirow[t]{2}{*}{ LNBOARDSIZE } & $0.2419 * *$ & $0.2217 *$ & 0.1147 & $0.2168 *$ & 0.0049 & 0.0041 & 0.0040 & 0.0149 \\
\hline & $(2.07)$ & $(1.96)$ & $(1.15)$ & $(1.94)$ & $(0.13)$ & $(0.10)$ & $(0.11)$ & $(0.41)$ \\
\hline \multirow[t]{2}{*}{ LNBOARDTEN } & 0.0400 & 0.0339 & 0.0822 & 0.0828 & -0.0608 & -0.0611 & $-0.1153 * * *$ & -0.0622 \\
\hline & $(0.48)$ & $(0.39)$ & $(1.07)$ & $(1.03)$ & $(-1.32)$ & $(-1.32)$ & $(-2.77)$ & $(-1.29)$ \\
\hline \multirow[t]{2}{*}{$L N B O A R D A G E$} & -1.2096 & -1.1608 & -0.1510 & $-1.7947 * *$ & 0.0620 & 0.0639 & 0.0053 & 0.0733 \\
\hline & $(-1.61)$ & $(-1.52)$ & $(-0.30)$ & $(-2.00)$ & $(0.32)$ & $(0.33)$ & $(0.03)$ & $(0.31)$ \\
\hline \multirow[t]{2}{*}{ BOARDDIVX } & & 0.3157 & 0.2733 & & & 0.0128 & 0.0056 & \\
\hline & & $(0.98)$ & $(0.65)$ & & & $(0.18)$ & $(0.07)$ & \\
\hline \multirow[t]{2}{*}{ BOARDWOM2 } & & & & -0.2916 & & & & 0.0283 \\
\hline & & & & $(-0.88)$ & & & & $(0.24)$ \\
\hline \multirow[t]{2}{*}{ BOARDEMPL2 } & & & & 1.0712 & & & & $-0.3483 * *$ \\
\hline & & & & $(1.51)$ & & & & $(-2.33)$ \\
\hline \multirow[t]{2}{*}{ BOARDNATMIX2 } & & & & 0.4276 & & & & $0.1285 * *$ \\
\hline & & & & $(1.29)$ & & & & $(2.24)$ \\
\hline \multirow[t]{2}{*}{$C V B O A R D A G E$} & & & & -0.4623 & & & & -0.1159 \\
\hline & & & & $(-1.06)$ & & & & $(-0.59)$ \\
\hline Bank-specific controls & Yes & Yes & Yes & Yes & Yes & Yes & Yes & Yes \\
\hline Country-specific controls & No & No & Yes & No & No & No & Yes & No \\
\hline Country fixed effects & Yes & Yes & No & Yes & Yes & Yes & No & Yes \\
\hline Year fixed effects & Yes & Yes & Yes & Yes & Yes & Yes & Yes & Yes \\
\hline Clustered SE (bank) & Yes & Yes & Yes & Yes & Yes & Yes & Yes & Yes \\
\hline No. of Obs. & 546 & 546 & 513 & 524 & 546 & 546 & 513 & 524 \\
\hline Adjusted R-squared & 0.271 & 0.272 & 0.260 & 0.303 & 0.550 & 0.549 & 0.505 & 0.556 \\
\hline
\end{tabular}

The table reports the main regression results of the effects of board features on bank performance and its variability measured by stock return (SR) and standard deviation of stock return (SDSR). Model (1) presents the results for the effects of banks' standard board features on their performance; Model (2) adds the board diversity index; Model (3) adds country-specific variables; Model (4) replaces the diversity index in Model (2) with the component diversity features. The models control for bank-specific characteristics, country fixed effects (except Model (3)) and time fixed effects. Bank-specific characteristics are winsorised at $99 \%$ of the bank-year distribution. All independent variables are lagged by one period. The t-statistics calculated using standard errors clustered at the bank level are reported in parentheses. *,**, and *** indicate significance at $10 \%, 5 \%$, and $1 \%$ levels, respectively. Definitions of the variables are provided in Appendix 1. 
Table 4 Non-linearity effects of board characteristics

\begin{tabular}{|c|c|c|c|c|c|c|}
\hline & \multicolumn{3}{|c|}{$S R$} & \multicolumn{3}{|c|}{ SDSR } \\
\hline & Model (1) & Model (2) & Model (3) & Model (1) & Model (2) & Model (3) \\
\hline DBOARDTYPE & $\begin{array}{c}-0.0214 \\
(-0.19)\end{array}$ & $\begin{array}{c}0.0366 \\
(0.37)\end{array}$ & $\begin{array}{c}0.1012 \\
(0.80)\end{array}$ & $\begin{array}{c}-0.0134 \\
(-0.30)\end{array}$ & $\begin{array}{c}-0.0150 \\
(-0.35)\end{array}$ & $\begin{array}{c}-0.0245 \\
(-0.51)\end{array}$ \\
\hline LNBOARDSIZE & & $\begin{array}{c}0.2214^{*} \\
(1.95)\end{array}$ & $\begin{array}{c}0.1879^{*} \\
(1.69)\end{array}$ & & $\begin{array}{c}0.0033 \\
(0.09)\end{array}$ & $\begin{array}{c}0.0119 \\
(0.32)\end{array}$ \\
\hline LNBOARDTEN & & $\begin{array}{l}0.0333 \\
(0.39)\end{array}$ & $\begin{array}{c}0.0736 \\
(0.87)\end{array}$ & & $\begin{array}{l}-0.0625 \\
(-1.35)\end{array}$ & $\begin{array}{c}-0.0635 \\
(-1.27)\end{array}$ \\
\hline$L N B O A R D A G E$ & & $\begin{array}{c}-1.1511 \\
(-1.48)\end{array}$ & $\begin{array}{c}-1.8142 * \\
(-1.87)\end{array}$ & & $\begin{array}{l}0.0868 \\
(0.46)\end{array}$ & $\begin{array}{c}0.0854 \\
(0.33)\end{array}$ \\
\hline LNBOARDSIZEUP & $\begin{array}{c}0.2986^{*} \\
(1.71)\end{array}$ & & & $\begin{array}{c}0.0126 \\
(0.25)\end{array}$ & & \\
\hline LNBOARDSIZEDN & $\begin{array}{c}0.3113 \\
(1.52)\end{array}$ & & & $\begin{array}{c}0.0161 \\
(0.29)\end{array}$ & & \\
\hline LNBOARDTENUP & $\begin{array}{l}-0.0225 \\
(-0.21)\end{array}$ & & & $\begin{array}{c}-0.0579 \\
(-1.08)\end{array}$ & & \\
\hline LNBOARDTENDN & $\begin{array}{c}-0.1135 \\
(-0.74)\end{array}$ & & & $\begin{array}{c}-0.0566 \\
(-0.87)\end{array}$ & & \\
\hline LNBOARDAGEUP & $\begin{array}{c}-0.9929 \\
(-1.06)\end{array}$ & & & $\begin{array}{c}0.2763 \\
(1.36)\end{array}$ & & \\
\hline LNBOARDAGEDN & $\begin{array}{l}-0.9774 \\
(-1.03)\end{array}$ & & & $\begin{array}{c}0.2900 \\
(1.41)\end{array}$ & & \\
\hline BOARDDIVXUP & & $\begin{array}{c}0.3401 \\
(0.96)\end{array}$ & & & $\begin{array}{c}0.0705 \\
(0.86)\end{array}$ & \\
\hline BOARDDIVXDN & & $\begin{array}{c}0.3783 \\
(0.77)\end{array}$ & & & $\begin{array}{c}0.1606 \\
(1.12)\end{array}$ & \\
\hline BOARDWOM $2 U P$ & & & $\begin{array}{c}-0.1788 \\
(-0.51)\end{array}$ & & & $\begin{array}{c}0.0316 \\
(0.27)\end{array}$ \\
\hline BOARDWOM2DN & & & $\begin{array}{c}0.7876 \\
(0.79)\end{array}$ & & & $\begin{array}{c}0.1667 \\
(0.60)\end{array}$ \\
\hline BOARDEMPL2UP & & & $\begin{array}{l}1.0127 \\
(1.46)\end{array}$ & & & $\begin{array}{c}-0.3547 * * * \\
(-2.37)\end{array}$ \\
\hline BOARDEMPL2DN & & & $\begin{array}{c}6.9161 * * \\
(2.15)\end{array}$ & & & $\begin{array}{c}-0.0997 \\
(-0.17)\end{array}$ \\
\hline BOARDNATMIX2UP & & & $\begin{array}{c}0.4285 \\
(1.38)\end{array}$ & & & $\begin{array}{c}0.1263^{* *} \\
(2.18)\end{array}$ \\
\hline BOARDNATMIX2DN & & & $\begin{array}{l}0.4350 \\
(0.97)\end{array}$ & & & $\begin{array}{l}0.1974 \\
(1.26)\end{array}$ \\
\hline CVBOARDAGEUP & & & $\begin{array}{l}-0.6527 \\
(-1.10)\end{array}$ & & & $\begin{array}{c}-0.0798 \\
(-0.32)\end{array}$ \\
\hline CVBOARDAGEDN & & & $\begin{array}{l}-0.8443 \\
(-0.79)\end{array}$ & & & $\begin{array}{l}0.0018 \\
(0.00)\end{array}$ \\
\hline Bank-specific controls & Yes & Yes & Yes & Yes & Yes & Yes \\
\hline Country fixed effects & Yes & Yes & Yes & Yes & Yes & Yes \\
\hline Year fixed effects & Yes & Yes & Yes & Yes & Yes & Yes \\
\hline Clustered SE (bank) & Yes & Yes & Yes & Yes & Yes & Yes \\
\hline No. of Obs. & 546 & 546 & 524 & 546 & 546 & 524 \\
\hline Adjusted R-squared & 0.272 & 0.270 & 0.300 & 0.552 & 0.550 & 0.553 \\
\hline
\end{tabular}


The table reports the results of the effects of board features on bank performance and its variability measured by stock return (SR) and standard deviation of stock return (SDSR) with the use of thresholds for the board variables, where suffixes UP and DN indicate a board variable value above and below its threshold level, respectively. Model (1) presents the results for the effects of banks' standard board features on their performance; Model (2) adds the board diversity index; Model (3) replaces the diversity index with the component diversity features. All the models control for bank-specific characteristics, country and time fixed effects. Bank-specific characteristics are winsorised at $99 \%$ of the bank-year distribution. All independent variables are lagged by one period. The t-statistics calculated using standard errors clustered at the bank level are reported in parentheses. ***, and $* * *$ indicate significance at $10 \%, 5 \%$, and $1 \%$ levels, respectively. Definitions of the variables are provided in Appendix 1. 
Table 5 Eurozone crisis and board characteristics

\begin{tabular}{|c|c|c|c|c|c|c|}
\hline & \multicolumn{3}{|c|}{$S R$} & \multicolumn{3}{|c|}{ SDSR } \\
\hline & Model (1) & Model (2) & Model (3) & Model (1) & Model (2) & Model (3) \\
\hline DBOARDTYPE & $\begin{array}{c}-0.0507 \\
(-0.61)\end{array}$ & $\begin{array}{c}0.0399 \\
(0.38)\end{array}$ & $\begin{array}{c}0.1302 \\
(0.88)\end{array}$ & $\begin{array}{c}0.0224 \\
(0.37)\end{array}$ & $\begin{array}{c}-0.0197 \\
(-0.45)\end{array}$ & $\begin{array}{c}-0.0174 \\
(-0.37)\end{array}$ \\
\hline ECDBOARDTYPE & $\begin{array}{l}0.0926 \\
(0.68)\end{array}$ & & & $\begin{array}{c}-0.0738 \\
(-0.91)\end{array}$ & & \\
\hline LNBOARDSIZE & $\begin{array}{c}0.3126 \\
(1.44)\end{array}$ & $\begin{array}{c}0.1746 \\
(1.62)\end{array}$ & $\begin{array}{c}0.1946 * \\
(1.71)\end{array}$ & $\begin{array}{c}-0.0279 \\
(-0.53)\end{array}$ & $\begin{array}{c}-0.0031 \\
(-0.08)\end{array}$ & $\begin{array}{c}0.0026 \\
(0.07)\end{array}$ \\
\hline ECLNBOARDSIZE & $\begin{array}{c}-0.0992 \\
(-0.41)\end{array}$ & & & $\begin{array}{c}0.0539 \\
(0.97)\end{array}$ & & \\
\hline LNBOARDTEN & $\begin{array}{c}0.2020 * \\
(1.87)\end{array}$ & $\begin{array}{l}0.0210 \\
(0.23)\end{array}$ & $\begin{array}{c}0.0677 \\
(0.76)\end{array}$ & $\begin{array}{c}-0.0562 \\
(-1.18)\end{array}$ & $\begin{array}{c}-0.0630 \\
(-1.38)\end{array}$ & $\begin{array}{c}-0.0713 \\
(-1.53)\end{array}$ \\
\hline ECLNBOARDTEN & $\begin{array}{c}-0.2242 \\
(-1.17)\end{array}$ & & & $\begin{array}{c}-0.0053 \\
(-0.10)\end{array}$ & & \\
\hline$L N B O A R D A G E$ & $\begin{array}{c}-2.1569 * * \\
(-2.54)\end{array}$ & $\begin{array}{c}-1.1772 \\
(-1.56)\end{array}$ & $\begin{array}{c}-2.0090^{* *} \\
(-2.17)\end{array}$ & $\begin{array}{c}-0.2420 \\
(-0.88)\end{array}$ & $\begin{array}{l}0.0614 \\
(0.32)\end{array}$ & $\begin{array}{c}0.1160 \\
(0.51)\end{array}$ \\
\hline ECLNBOARDAGE & $\begin{array}{l}1.3091 \\
(1.25)\end{array}$ & & & $\begin{array}{c}0.4665^{* *} \\
(2.04)\end{array}$ & & \\
\hline BOARDDIVX & & $\begin{array}{l}1.1534 \\
(1.11)\end{array}$ & & & $\begin{array}{c}0.1406 \\
(1.28)\end{array}$ & \\
\hline ECBOARDDIVX & & $\begin{array}{c}-1.2532 \\
(-1.08)\end{array}$ & & & $\begin{array}{c}-0.1912^{*} \\
(-1.74)\end{array}$ & \\
\hline BOARDWOM2 & & & $\begin{array}{c}-1.1610 \\
(-1.53)\end{array}$ & & & $\begin{array}{c}0.1403 \\
(0.86)\end{array}$ \\
\hline ECBOARDWOM2 & & & $\begin{array}{l}1.1788 \\
(1.38)\end{array}$ & & & $\begin{array}{c}-0.1976 \\
(-1.30)\end{array}$ \\
\hline BOARDEMPL2 & & & $\begin{array}{c}2.3239 \\
(1.59)\end{array}$ & & & $\begin{array}{c}-0.2669 \\
(-1.35)\end{array}$ \\
\hline ECBOARDEMPL2 & & & $\begin{array}{c}-1.7080 \\
(-1.42)\end{array}$ & & & $\begin{array}{c}-0.1643 \\
(-1.15)\end{array}$ \\
\hline BOARDNATMIX2 & & & $\begin{array}{l}1.3336 \\
(1.36)\end{array}$ & & & $\begin{array}{c}0.2616^{* * * *} \\
\quad(3.22)\end{array}$ \\
\hline ECBOARDNATMIX2 & & & $\begin{array}{c}-1.2839 \\
(-1.32)\end{array}$ & & & $\begin{array}{c}-0.1970 * * \\
(-2.10)\end{array}$ \\
\hline CVBOARDAGE & & & $\begin{array}{l}1.8911 \\
(0.80)\end{array}$ & & & $\begin{array}{c}-0.6374 \\
(-1.23)\end{array}$ \\
\hline ECCVBOARDAGE & & & $\begin{array}{l}-2.9492 \\
(-1.08)\end{array}$ & & & $\begin{array}{c}0.6902 \\
(1.34)\end{array}$ \\
\hline Bank-specific controls & Yes & Yes & Yes & Yes & Yes & Yes \\
\hline Country fixed effects & Yes & Yes & Yes & Yes & Yes & Yes \\
\hline Year fixed effects & Yes & Yes & Yes & Yes & Yes & Yes \\
\hline Clustered SE (bank) & Yes & Yes & Yes & Yes & Yes & Yes \\
\hline No. of Obs. & 546 & 546 & 524 & 546 & 546 & 524 \\
\hline Adjusted R-squared & 0.270 & 0.287 & 0.344 & 0.553 & 0.552 & 0.566 \\
\hline
\end{tabular}


The table reports the results of the impact of the Eurozone crisis on the association between board features and bank performance and its variability measured by stock return (SR) and standard deviation of stock return (SDSR). Model (1) includes standard board features and their interactions with the Eurozone crisis dummy (the latter is equal to 1 for years 2010-2014 and zero for years 2007-2009); Model (2) includes the board diversity index and its interaction with the Eurozone crisis dummy; Model (3) replaces the diversity index and its interaction with the Eurozone crisis dummy with the component diversity features and their interactions with the Eurozone crisis dummy. All models control for bank-specific characteristics, country and time fixed effects. Bank-specific characteristics are winsorised at $99 \%$ of the bank-year distribution. All independent variables are lagged by one period. The t-statistics calculated using standard errors clustered at the bank level are reported in parentheses. *,**, and *** indicate significance at $10 \%$, $5 \%$, and $1 \%$ levels, respectively. Definitions of the variables are provided in Appendix 1. 
Table 6 Openness to diversity and board characteristics

\begin{tabular}{|c|c|c|c|c|}
\hline & \multicolumn{2}{|c|}{$S R$} & \multicolumn{2}{|c|}{ SDSR } \\
\hline & Model (1) & Model (2) & Model (1) & Model (2) \\
\hline DBOARDTYPE & $\begin{array}{c}-0.0747 \\
(-1.29)\end{array}$ & $\begin{array}{c}0.0383 \\
(0.26)\end{array}$ & $\begin{array}{c}0.0022 \\
(0.06)\end{array}$ & $\begin{array}{c}0.0154 \\
(0.41)\end{array}$ \\
\hline LNBOARDSIZE & $\begin{array}{c}0.1889 * \\
(1.76)\end{array}$ & $\begin{array}{c}0.1345 \\
(1.14)\end{array}$ & $\begin{array}{c}0.0065 \\
(0.17)\end{array}$ & $\begin{array}{c}0.0149 \\
(0.35)\end{array}$ \\
\hline LNBOARDTEN & $\begin{array}{c}0.0993 \\
(1.35)\end{array}$ & $\begin{array}{c}0.1553 * * \\
(2.14)\end{array}$ & $\begin{array}{c}-0.0820 * \\
(-1.72)\end{array}$ & $\begin{array}{c}-0.0816^{*} \\
(-1.67)\end{array}$ \\
\hline$L N B O A R D A G E$ & $\begin{array}{c}-0.7083 \\
(-1.55)\end{array}$ & $\begin{array}{c}-1.1397 * * \\
(-2.60)\end{array}$ & $\begin{array}{c}-0.0071 \\
(-0.04)\end{array}$ & $\begin{array}{c}-0.0418 \\
(-0.18)\end{array}$ \\
\hline BOARDDIVX & $\begin{array}{c}0.1681 \\
(0.70)\end{array}$ & & $\begin{array}{c}0.1745^{* *} \\
(2.28)\end{array}$ & \\
\hline HOFBOARDDIVX & $\begin{array}{c}0.2270 \\
(0.39)\end{array}$ & & $\begin{array}{c}-0.2979 * \\
(-1.81)\end{array}$ & \\
\hline BOARDWOM2 & & $\begin{array}{c}0.3971 \\
(1.03)\end{array}$ & & $\begin{array}{c}-0.0040 \\
(-0.03)\end{array}$ \\
\hline HOFBOARDWOM 2 & & $\begin{array}{c}-1.0785 * \\
(-1.71)\end{array}$ & & $\begin{array}{c}0.0346 \\
(0.15)\end{array}$ \\
\hline BOARDEMPL2 & & $\begin{array}{c}-0.6898 \\
(-0.62)\end{array}$ & & $\begin{array}{c}-0.2470 \\
(-1.00)\end{array}$ \\
\hline HOFBOARDEMPL2 & & $\begin{array}{c}2.1634 \\
(1.21)\end{array}$ & & $\begin{array}{c}-0.0394 \\
(-0.12)\end{array}$ \\
\hline BOARDNATMIX2 & & $\begin{array}{c}0.0680 \\
(0.32)\end{array}$ & & $\begin{array}{c}0.2705 * * * \\
\quad(3.07)\end{array}$ \\
\hline HOFBOARDNATMIX2 & & $\begin{array}{c}0.6148 \\
(1.10)\end{array}$ & & $\begin{array}{c}-0.2760 * \\
(-1.96)\end{array}$ \\
\hline CVBOARDAGE & & $\begin{array}{c}-0.4643 \\
(-1.22)\end{array}$ & & $\begin{array}{c}-0.0047 \\
(-0.03)\end{array}$ \\
\hline HOFCVBOARDAGE & & $\begin{array}{c}1.6287 \\
(1.10)\end{array}$ & & $\begin{array}{c}-0.5432 \\
(-0.90)\end{array}$ \\
\hline Bank-specific controls & Yes & Yes & Yes & Yes \\
\hline Country fixed effects & Yes & Yes & Yes & Yes \\
\hline Year fixed effects & Yes & Yes & Yes & Yes \\
\hline Clustered SE (bank) & Yes & Yes & Yes & Yes \\
\hline No. of Obs. & 527 & 505 & 527 & 505 \\
\hline Adjusted R-squared & 0.273 & 0.312 & 0.559 & 0.566 \\
\hline
\end{tabular}

The table reports the results of the impact of the countries' openness to diversity on the association between board diversity features and bank performance and its variability measured by stock return (SR) and standard deviation of stock return (SDSR). Model (1) includes the diversity index and its interaction with the Hofstede dummy (the latter is equal to 1 for countries more open to diversity and zero otherwise); Model (2) replaces the diversity index and its interaction with the Hofstede dummy with the component diversity features and their interactions with the Hofstede dummy. All models control for bank-specific characteristics, country and time fixed effects. Bank-specific characteristics are winsorised at $99 \%$ of the bank-year distribution. All independent variables are lagged by one period. The t-statistics calculated using standard errors clustered at the bank level are reported in parentheses. *, **, and *** indicate significance at $10 \%, 5 \%$, and $1 \%$ levels, respectively. Definitions of the variables are provided in Appendix 1. 
Table 7 Alternative performance measures

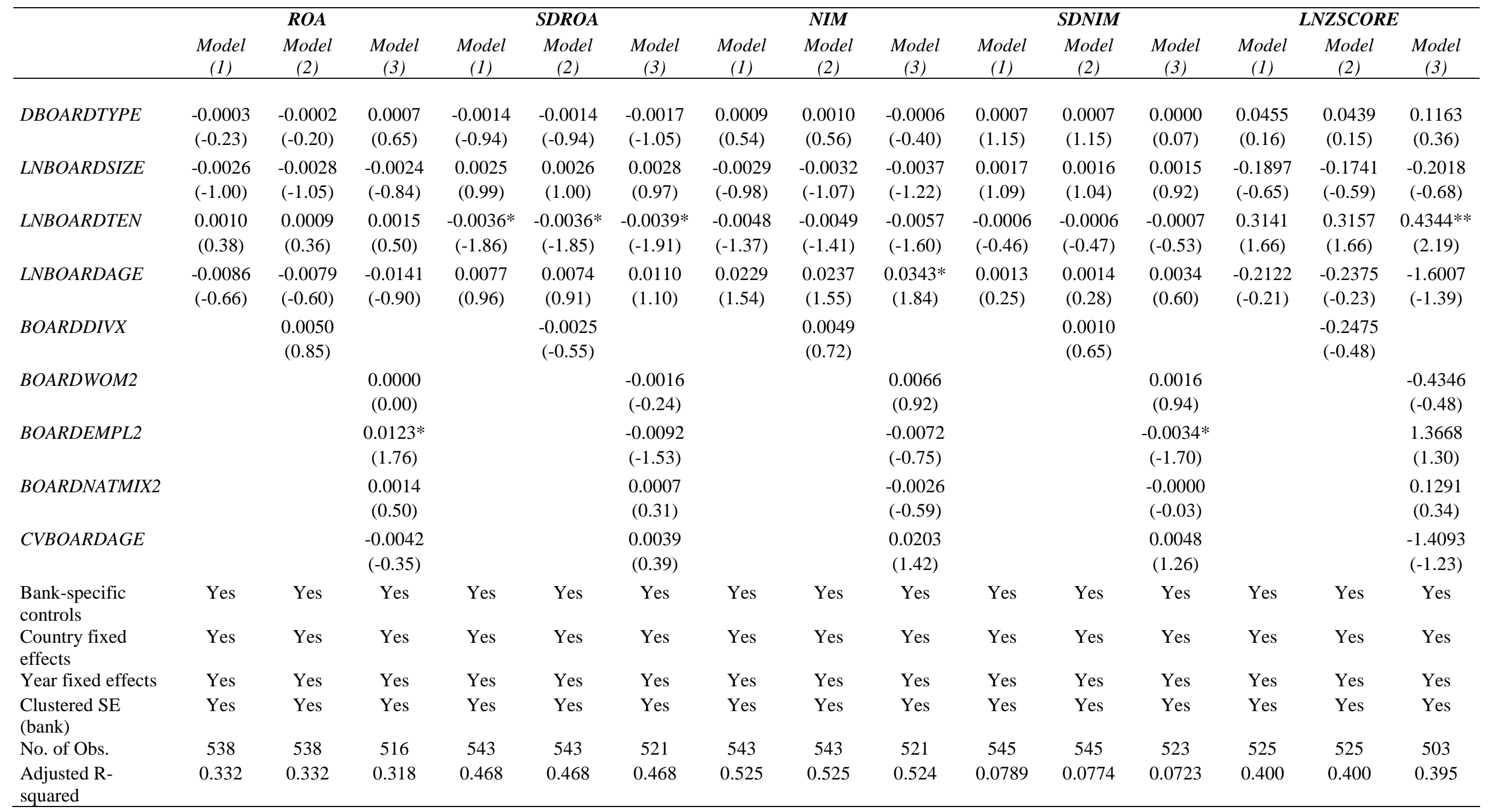




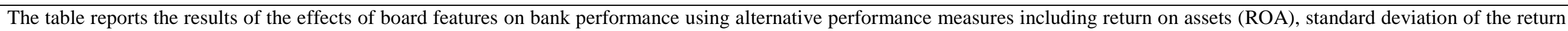

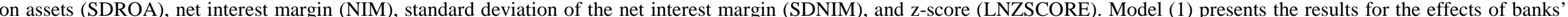

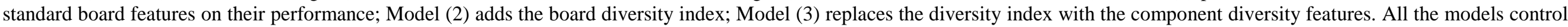

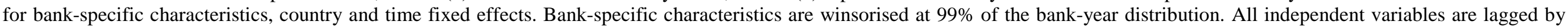

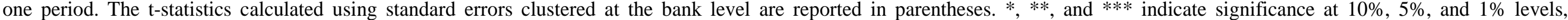
respectively. Definitions of the variables are provided in Appendix 1. 


\begin{tabular}{|c|c|c|c|c|c|c|}
\hline & \multicolumn{3}{|c|}{$S R$} & \multicolumn{3}{|c|}{ SDSR } \\
\hline & Model (1) & Model (2) & Model (3) & Model (1) & Model (2) & Model (3) \\
\hline \multirow[t]{2}{*}{ DBOARDTYPE } & -0.0434 & 0.0833 & 0.2062 & 0.0186 & 0.0301 & -0.0342 \\
\hline & $(-0.08)$ & $(0.23)$ & $(0.46)$ & $(0.84)$ & $(0.41)$ & $(-0.36)$ \\
\hline \multirow[t]{2}{*}{$L N B O A R D S I Z E$} & -0.1295 & -0.0728 & -0.2211 & -0.0556 & -0.0120 & -0.0570 \\
\hline & $(-0.41)$ & $(-0.28)$ & $(-0.71)$ & $(-1.63)$ & $(-0.19)$ & $(-0.63)$ \\
\hline \multirow[t]{2}{*}{ LNBOARDTEN } & -0.2216 & -0.0578 & 0.0518 & $-0.1101 * * *$ & $-0.1087 *$ & -0.0541 \\
\hline & $(-1.32)$ & $(-0.28)$ & $(0.25)$ & $(-3.96)$ & $(-1.68)$ & $(-0.88)$ \\
\hline \multirow[t]{2}{*}{$L N B O A R D A G E$} & 1.3934 & 0.3421 & 0.5788 & $0.3253 * * *$ & 0.3009 & 0.1796 \\
\hline & $(1.22)$ & $(0.31)$ & $(0.37)$ & $(2.90)$ & $(1.03)$ & $(0.56)$ \\
\hline \multirow[t]{2}{*}{ BOARDDIVX } & & 0.2012 & & & -0.0724 & \\
\hline & & $(0.34)$ & & & $(-0.61)$ & \\
\hline \multirow[t]{2}{*}{ BOARDWOM2 } & & & -0.0331 & & & 0.0907 \\
\hline & & & $(-0.04)$ & & & $(0.32)$ \\
\hline \multirow[t]{2}{*}{ BOARDEMPL2 } & & & 0.4384 & & & $-0.5551 * *$ \\
\hline & & & $(0.54)$ & & & $(-2.42)$ \\
\hline \multirow[t]{2}{*}{ BOARDNATMIX2 } & & & 0.2103 & & & 0.0228 \\
\hline & & & $(0.44)$ & & & $(0.18)$ \\
\hline \multirow[t]{2}{*}{$C V B O A R D A G E$} & & & 0.1208 & & & -0.0276 \\
\hline & & & $(0.07)$ & & & $(-0.08)$ \\
\hline $\begin{array}{l}\text { Bank-specific } \\
\text { controls }\end{array}$ & Yes & Yes & Yes & Yes & Yes & Yes \\
\hline Year time effect & Yes & Yes & Yes & Yes & Yes & Yes \\
\hline No. of Obs. & 546 & 546 & 524 & 546 & 546 & 524 \\
\hline \multirow[t]{2}{*}{ Hansen (df) } & 53.99 & 57.84 & 53.04 & 64.93 & 64.14 & 58.14 \\
\hline & $(274)$ & (294) & $(333)$ & $(274)$ & $(294)$ & $(333)$ \\
\hline $\operatorname{AR}(1)$ & $-1.795^{*}$ & $-2.060 * *$ & $-3.221 * * *$ & $-1.928 *$ & $-1.887 *$ & $-1.843 *$ \\
\hline $\operatorname{AR}(2)$ & -1.345 & -1.323 & $-1.767 *$ & $-2.293 * *$ & $-2.184 * *$ & $-1.905 *$ \\
\hline
\end{tabular}

The table reports the results of the two-step Dynamic Panel System GMM regressions of performance and its variability measured by stock return (SR) and standard deviation of stock return (SDSR) on standard and diversity board features, bank-specific control variables and year fixed effects. Model (1) presents the results for the effects of banks' standard board features; Model (2) adds the board diversity index; Model (3) replaces the board diversity index with the component diversity features. Bank-specific characteristics are winsorised at $99 \%$ of the bank-year distribution. All independent variables are treated as endogenous. Endogenous variables are instrumented by one of their past values. The t-statistics calculated using Windmeijer's robust standard errors are reported in parentheses. The null hypothesis for the Hansen test of overidentification is that all instruments are exogenous. $\operatorname{AR}(1)$ and $\operatorname{AR}(2)$ are test statistics for the null hypothesis that there is no serial correlation of order 1 and 2 in the first-difference residuals. *, **, *** denote statistical significance at $10 \%, 5 \%$, and $1 \%$ respectively. Definitions of the variables are provided in Appendix 1. 
Table 9 Two-step DPS-GMM: Alternative performance measures

\begin{tabular}{|c|c|c|c|c|c|c|c|c|c|c|c|c|c|c|c|}
\hline & \multicolumn{3}{|c|}{$R O A$} & \multicolumn{3}{|c|}{ SDROA } & \multicolumn{3}{|c|}{ NIM } & \multicolumn{3}{|c|}{ SDNIM } & \multicolumn{3}{|c|}{ LNZSCORE } \\
\hline & Model (1) & Model (2) & Model (3) & Model (1) & $\begin{array}{c}\text { Model } \\
\text { (2) }\end{array}$ & $\begin{array}{c}\text { Model } \\
\text { (3) }\end{array}$ & $\begin{array}{l}\text { Model } \\
(1) \\
\end{array}$ & $\begin{array}{c}\text { Model } \\
(2)\end{array}$ & $\begin{array}{c}\text { Model } \\
\text { (3) }\end{array}$ & Model (1) & $\begin{array}{c}\text { Model } \\
(2)\end{array}$ & $\begin{array}{l}\text { Model } \\
\text { (3) }\end{array}$ & Model (1) & Model (2) & Model (3) \\
\hline DBOARDTYPE & $\begin{array}{c}0.0005 \\
(0.11)\end{array}$ & $\begin{array}{c}-0.0004 \\
(-0.10)\end{array}$ & $\begin{array}{c}-0.0066 \\
(-0.80)\end{array}$ & $\begin{array}{c}-0.0020 \\
(-0.43)\end{array}$ & $\begin{array}{l}-0.0021 \\
(-0.41)\end{array}$ & $\begin{array}{c}-0.0060 \\
(-1.29)\end{array}$ & $\begin{array}{c}0.0014 \\
(0.33)\end{array}$ & $\begin{array}{c}0.0051 \\
(1.28)\end{array}$ & $\begin{array}{c}0.0013 \\
(0.29)\end{array}$ & $\begin{array}{c}0.0011 \\
(1.34)\end{array}$ & $\begin{array}{c}0.0013 \\
(1.02)\end{array}$ & $\begin{array}{c}0.0014 \\
(0.80)\end{array}$ & $\begin{array}{c}-0.6626 \\
(-0.95)\end{array}$ & $\begin{array}{c}-0.5826 \\
(-0.94)\end{array}$ & $\begin{array}{c}0.4754 \\
(0.73)\end{array}$ \\
\hline LNBOARDSIZE & $\begin{array}{c}-0.0036 \\
(-1.23)\end{array}$ & $\begin{array}{c}-0.0034 \\
(-0.88)\end{array}$ & $\begin{array}{c}-0.0043 \\
(-0.91)\end{array}$ & $\begin{array}{c}0.0000 \\
(0.02)\end{array}$ & $\begin{array}{c}0.0003 \\
(0.10)\end{array}$ & $\begin{array}{c}0.0035 \\
(0.85)\end{array}$ & $\begin{array}{c}-0.0015 \\
(-0.38)\end{array}$ & $\begin{array}{c}-0.0037 \\
(-0.99)\end{array}$ & $\begin{array}{c}-0.0011 \\
(-0.31)\end{array}$ & $\begin{array}{c}-0.0007 \\
(-0.91)\end{array}$ & $\begin{array}{c}-0.0005 \\
(-0.47)\end{array}$ & $\begin{array}{c}-0.0013 \\
(-1.05)\end{array}$ & $\begin{array}{c}-0.0857 \\
(-0.16)\end{array}$ & $\begin{array}{c}0.0671 \\
(0.09)\end{array}$ & $\begin{array}{c}-0.2975 \\
(-0.58)\end{array}$ \\
\hline LNBOARDTEN & $\begin{array}{c}0.0036 \\
(1.44)\end{array}$ & $\begin{array}{c}0.0022 \\
(0.56)\end{array}$ & $\begin{array}{c}0.0009 \\
(0.25)\end{array}$ & $\begin{array}{c}-0.0058 * * \\
(-2.36)\end{array}$ & $\begin{array}{c}-0.0051^{*} \\
(-1.87)\end{array}$ & $\begin{array}{c}-0.0053^{*} \\
(-1.93)\end{array}$ & $\begin{array}{c}-0.0027 \\
(-0.85)\end{array}$ & $\begin{array}{c}0.0009 \\
(0.27)\end{array}$ & $\begin{array}{c}0.0002 \\
(0.05)\end{array}$ & $\begin{array}{c}-0.0017 * * * \\
(-3.75)\end{array}$ & $\begin{array}{c}-0.0013 \\
(-1.51)\end{array}$ & $\begin{array}{c}-0.0017 * \\
(-1.94)\end{array}$ & $\begin{array}{c}0.3023 \\
(0.89)\end{array}$ & $\begin{array}{c}0.4662 \\
(1.09)\end{array}$ & $\begin{array}{c}0.4446 \\
(0.90)\end{array}$ \\
\hline LNBOARDAGE & $\begin{array}{c}0.0021 \\
(0.19)\end{array}$ & $\begin{array}{c}-0.0006 \\
(-0.04)\end{array}$ & $\begin{array}{c}0.0076 \\
(0.37)\end{array}$ & $\begin{array}{c}0.0200 \\
(1.50)\end{array}$ & $\begin{array}{c}0.0200 \\
(1.12)\end{array}$ & $\begin{array}{c}0.0174 \\
(1.54)\end{array}$ & $\begin{array}{c}0.0211 \\
(0.99)\end{array}$ & $\begin{array}{c}0.0148 \\
(0.62)\end{array}$ & $\begin{array}{c}0.0063 \\
(0.24)\end{array}$ & $\begin{array}{c}0.0028 \\
(0.86)\end{array}$ & $\begin{array}{c}0.0023 \\
(0.51)\end{array}$ & $\begin{array}{c}0.0031 \\
(0.75)\end{array}$ & $\begin{array}{c}0.1308 \\
(0.06)\end{array}$ & $\begin{array}{c}0.4407 \\
(0.19)\end{array}$ & $\begin{array}{l}1.5693 \\
(0.54)\end{array}$ \\
\hline BOARDDIVX & & $\begin{array}{c}0.0062 \\
(0.76)\end{array}$ & & & $\begin{array}{c}-0.0008 \\
(-0.15)\end{array}$ & & & $\begin{array}{c}-0.0012 \\
(-0.15)\end{array}$ & & & $\begin{array}{c}0.0015 \\
(0.79)\end{array}$ & & & $\begin{array}{c}0.2197 \\
(0.24)\end{array}$ & \\
\hline BOARDWOM 2 & & & $\begin{array}{c}-0.0108 \\
(-0.86)\end{array}$ & & & $\begin{array}{c}0.0013 \\
(0.18)\end{array}$ & & & $\begin{array}{l}-0.0055 \\
(-0.46)\end{array}$ & & & $\begin{array}{c}0.0010 \\
(0.31)\end{array}$ & & & $\begin{array}{c}0.7090 \\
(0.39)\end{array}$ \\
\hline BOARDEMPL2 & & & $\begin{array}{c}0.0115 \\
(0.90)\end{array}$ & & & $\begin{array}{c}-0.0085 \\
(-0.78)\end{array}$ & & & $\begin{array}{c}0.0092 \\
(0.83)\end{array}$ & & & $\begin{array}{c}-0.0011 \\
(-0.39)\end{array}$ & & & $\begin{array}{c}2.8994 \\
(1.38)\end{array}$ \\
\hline BOARDNATMIX2 & & & $\begin{array}{c}-0.0030 \\
(-0.51)\end{array}$ & & & $\begin{array}{c}0.0007 \\
(0.26)\end{array}$ & & & $\begin{array}{c}-0.0030 \\
(-0.49)\end{array}$ & & & $\begin{array}{c}0.0002 \\
(0.14)\end{array}$ & & & $\begin{array}{c}0.0390 \\
(0.04)\end{array}$ \\
\hline CVBOARDAGE & & & $\begin{array}{c}0.0032 \\
(0.19)\end{array}$ & & & $\begin{array}{c}0.0209 \\
(0.87)\end{array}$ & & & $\begin{array}{c}-0.0017 \\
(-0.07)\end{array}$ & & & $\begin{array}{c}0.0015 \\
(0.54)\end{array}$ & & & $\begin{array}{c}0.1858 \\
(0.08)\end{array}$ \\
\hline $\begin{array}{l}\text { Bank-specific } \\
\text { controls }\end{array}$ & Yes & Yes & Yes & Yes & Yes & Yes & Yes & Yes & Yes & Yes & Yes & Yes & Yes & Yes & Yes \\
\hline Year time effect & Yes & Yes & Yes & Yes & Yes & Yes & Yes & Yes & Yes & Yes & Yes & Yes & Yes & Yes & Yes \\
\hline No. of Obs. & 543 & 543 & 521 & 544 & 544 & 522 & 546 & 546 & 524 & 546 & 546 & 524 & 531 & 531 & 509 \\
\hline Hansen (df) & $\begin{array}{l}44.56 \\
(274)\end{array}$ & $\begin{array}{l}54.12 \\
(294)\end{array}$ & $\begin{array}{l}58.53 \\
(332)\end{array}$ & $\begin{array}{l}57.89 \\
(274)\end{array}$ & $\begin{array}{l}57.90 \\
(294)\end{array}$ & $\begin{array}{l}47.53 \\
(332)\end{array}$ & $\begin{array}{l}60.37 \\
(222)\end{array}$ & $\begin{array}{l}55.65 \\
(294)\end{array}$ & $\begin{array}{l}53.87 \\
(333)\end{array}$ & $\begin{array}{l}52.32 \\
(274)\end{array}$ & $\begin{array}{l}54.32 \\
(294)\end{array}$ & $\begin{array}{l}45.03 \\
(333)\end{array}$ & $\begin{array}{l}61.34 \\
(274)\end{array}$ & $\begin{array}{l}64.54 \\
(293)\end{array}$ & $\begin{array}{l}58.71 \\
(326)\end{array}$ \\
\hline $\operatorname{AR}(1)$ & $-2.563 * *$ & $-2.580 * * *$ & $-2.635 * * *$ & $-1.681^{*}$ & $-1.657 *$ & -1.451 & $-1.829 *$ & $-1.869 *$ & $-1.682 *$ & -1.460 & -1.542 & -1.324 & $-3.033 * * *$ & $-2.793 * * *$ & $-2.615 * * *$ \\
\hline $\operatorname{AR}(2)$ & -0.122 & 0.110 & -0.0724 & 1.624 & 1.599 & 1.554 & -0.416 & -0.299 & -0.149 & $-1.932 *$ & $-1.802 *$ & $-1.946^{*}$ & -1.558 & -1.340 & -1.631 \\
\hline
\end{tabular}




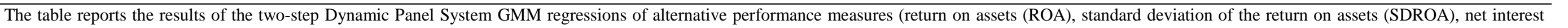

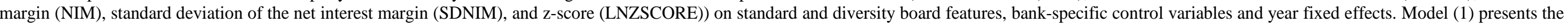

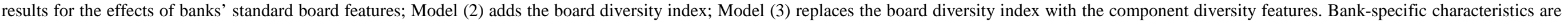

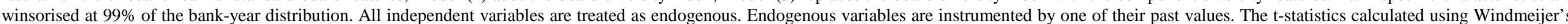

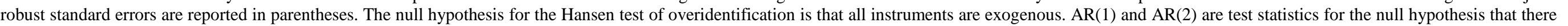

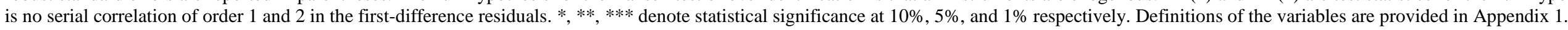




\section{Appendix 1 Variable definitions}

\begin{tabular}{|c|c|c|}
\hline Variable & Definition & Source \\
\hline \multicolumn{3}{|c|}{ Performance Variables } \\
\hline$S R$ & Daily stock return (annual average) & Datastream (now Thomson Eikon) \\
\hline SDDSR & Standard deviation of SR (t, t-1, t-2) & $\begin{array}{l}\text { Authors' calculation using Datastream (now } \\
\text { Thomson Eikon) }\end{array}$ \\
\hline$R O A$ & Return on Assets (annual dataO & Bankscope data (now Orbis Bank Focus) \\
\hline SDROA & Standard deviation of ROA (t, t-1, t-2) & $\begin{array}{l}\text { Authors' calculation using Bankscope data } \\
\text { (now Orbis Bank Focus) }\end{array}$ \\
\hline NIM & Net interest margin (annual data) & Bankscope (now Orbis Bank Focus) \\
\hline SDNIM & Standard deviation of NIM (t, t-1, t-2) & $\begin{array}{l}\text { Authors' calculation using Bankscope data } \\
\text { (now Orbis Bank Focus) }\end{array}$ \\
\hline ZSCORE & $\begin{array}{l}\text { (3-year average return on assets }+3 \text {-year average equity } \\
\text { capital ratio)/3-year standard deviation of return on assets }\end{array}$ & $\begin{array}{l}\text { Authors' calculation using Bankscope data } \\
\text { (now Orbis Bank Focus) }\end{array}$ \\
\hline LNZSCORE & $\operatorname{Ln}(Z S C O R E)$ & $\begin{array}{l}\text { Authors' calculation using Bankscope data } \\
\text { (now Orbis Bank Focus) }\end{array}$ \\
\hline \multicolumn{3}{|c|}{ Board variables - Standard } \\
\hline DBOARDTYPE & Dummy equal to 0 if board is one tier and 1 if two tier & BoardEx \\
\hline BOARDSIZE & Board size $=$ Number of board members & BoardEx \\
\hline LNBOARDSIZE & $\operatorname{Ln}(B O A R D S I Z E)$ & Authors' calculation using BoardEx data \\
\hline BOARDTEN & Board tenure (years) & BoardEx \\
\hline LNBOARDTEN & $\operatorname{Ln}(B O A R D T E N)$ & Authors' calculation using BoardEx data \\
\hline BOARDAGE & Board age $=$ Average age of board members (years) & BoardEx \\
\hline$L N B O A R D A G E$ & $\operatorname{Ln}(B O A R D A G E)$ & Authors' calculation using BoardEx data \\
\hline \multicolumn{3}{|c|}{ Board variables - Diversity } \\
\hline BOARDDIVX & $\begin{array}{l}\text { Diversity index }=(1) \text { The board diversity variables } \\
(B O A R D W O M 2, \text { BOARDEMPL2, BOARDNATMIX2, } \\
\text { and CVBOARDAGE) are converted into discrete } \\
\text { variables ranging from } 1 \text { to } 10 \text { based on the decile of the } \\
\text { sample distribution they fall into (with } 1 \text { being the bottom } \\
\text { and } 10 \text { the top decile); (2) the diversity index for each } \\
\text { bank-year is computed as BOARDDIVX } \mathrm{i}_{\mathrm{it}}=\frac{1}{40} \sum_{\mathrm{j}=1}^{4} \mathrm{D}_{\mathrm{it}}^{\mathrm{j}} \\
\text { The index ranges from } 0 \text { (low diversity) to } 1 \text { (high } \\
\text { diversity). }\end{array}$ & Authors' calculation using BoardEx data \\
\hline DBOARDWOM & $\begin{array}{l}\text { Dummy equal to } 1 \text { if both genders are represented on the } \\
\text { board and } 0 \text { if the board is formed exclusively by men }\end{array}$ & Authors' calculation using BoardEx data \\
\hline BOARDWOM & Number of women on the board & BoardEx \\
\hline BOARDWOM2 & Fraction of women on the board & Authors' calculation using BoardEx data \\
\hline$D B O A R D E M P L$ & $\begin{array}{l}\text { Dummy equal to } 1 \text { if employees are present on the board } \\
\text { and } 0 \text { otherwise }\end{array}$ & Authors' calculation using BoardEx data \\
\hline$B O A R D E M P L$ & Number of employees on the board & BoardEx \\
\hline BOARDEMPL2 & Fraction of employees on the board & Authors' calculation using BoardEx data \\
\hline DBOARDNATMIX & $\begin{array}{l}\text { Dummy equal to } 1 \text { if percentage of foreign members on } \\
\text { the board greater than } 0 \text { and } 0 \text { if the board is formed } \\
\text { exclusively by domestic members }\end{array}$ & Authors' calculation using BoardEx data \\
\hline BOARDNATMIX2 & $\begin{array}{l}\text { Nationality mix }=\text { Percentage of foreign members on the } \\
\text { board }\end{array}$ & BoardEx \\
\hline CVBOARDAGE & $\begin{array}{l}\text { Coefficient of variation of board members' age }= \\
\text { Standard deviation of board age/BOARDAGE }\end{array}$ & Authors' calculation using BoardEx data \\
\hline \multicolumn{3}{|c|}{ Bank-specific variables } \\
\hline$T A B L$ & Total assets (Euro billions) & \\
\hline LNTA & $\operatorname{Ln}(T A B L)$ & $\begin{array}{l}\text { Authors' calculation using Bankscope data } \\
\text { (now Orbis Bank Focus) }\end{array}$ \\
\hline$T A G A$ & Total asset growth & $\begin{array}{l}\text { Authors' calculation using Bankscope data } \\
\text { (now Orbis Bank Focus) }\end{array}$ \\
\hline LOANTA & Loan ratio $=$ Gross loans to total assets & $\begin{array}{l}\text { Authors' calculation using Bankscope data } \\
\text { (now Orbis Bank Focus) }\end{array}$ \\
\hline TDTA & $\begin{array}{l}\text { Deposit ratio }=\text { Deposit and short-term funding to total } \\
\text { assets }\end{array}$ & $\begin{array}{l}\text { Authors' calculation using Bankscope data } \\
\text { (now Orbis Bank Focus) }\end{array}$ \\
\hline ETA & Equity to total assets & Bankscope (now Orbis Bank Focus) \\
\hline$L L P L O A N$ & Quality of loan portfolio $=$ Loan loss provisions to gross & Authors' calculation using Bankscope data \\
\hline
\end{tabular}


loans

CI

Country-specific variables

LEGAL

$G D P C$

$L N G D P C$

HHI

CMC

LNCMC

EUROCRISIS

HOF

DHOF

Thresholds

LNBOARDSIZEUP

LNBOARDSIZEDN

LNBOARDTENUP

LNBOARDTENDN

LNBOARDAGEUP

LNBOARDAGEDN

BOARDDIVXUP

BOARDDIVXDN

BOARDWOM2UP

BOARDWOM2DN

BOARDEMPL2UP

BOARDEMPL2DN

BOARDNATMIX2UP

BOARDNATMIX2DN

Interactions

ECDBOARDTYPE

ECLNBOARDSIZE

ECLNBOARDTEN

ECLNBOARDAGE

ECBOARDDIVX

ECBOARDWOM2

ECBOARDEMPL2

ECBOARDNATMIX2

ECCVBOARDAGE

HOFBOARDDIVX

HOFBOARDWOM2

HOFBOARDEMPL2

HOFBOARDNATMIX2

HOFCVBOARDAGE
Cost to income ratio (\%)

Dummy equal to 1 if country has a common law legal system and 0 otherwise

GDP in Euro per capita

$\operatorname{Ln}(G D P C)$

Banking sector concentration $=$ Herfindahl Hirschman Index $(\%)$

Country market capitalisation (Euro millions)

$\operatorname{Ln}(C M C)$

Eurozone crisis dummy equal to 1 for years 2010-2014 and 0 otherwise

Hofstede index $=$ The average value across the six Hofstede dimensions of national culture (i.e., (100 power distance), individualism, (100 - masculinity), (100 - uncertainty avoidance), long-term orientation, and indulgence)

Hofstede dummy equal to 1 if $H O F$ is above the sample mean (greater national openness to diversity) and 0 otherwise (lower national openness to diversity)

LNBOARDSIZE above its threshold level LNBOARDSIZE below its threshold level LNBOARDTEN above its threshold level LNBOARDTEN below its threshold level $L N B O A R D A G E$ above its threshold level $L N B O A R D A G E$ below its threshold level $B O A R D D I V X$ above its threshold level $B O A R D D I V X$ below its threshold level BOARDWOM2 above its threshold level BOARDWOM2 below its threshold level BOARDEMPL2 above its threshold level $B O A R D E M P L 2$ below its threshold level BOARDNATMIX2 above its threshold level BOARDNATMIX2 below its threshold level

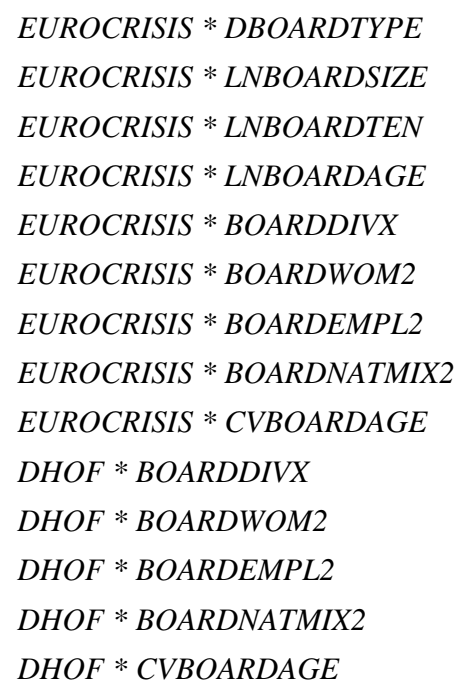

(now Orbis Bank Focus)

Bankscope (now Orbis Bank Focus)

Authors' calculation using data from CIA, Commonwealth network, NYU Law Global and Hatzimihail (2013)

Authors' calculation using Eurostat data

Authors' calculation using Eurostat data

ECB statistical data warehouse

Authors' calculation using World Federation of Exchanges (WFE) and ECB data

Authors' calculation using World Federation of Exchanges (WFE) and ECB data

Authors' calculation

Authors' calculation using the Hofstede Insight data

Authors' calculation

Authors' calculation

Authors' calculation

Authors' calculation

Authors' calculation

Authors' calculation

Authors' calculation

Authors' calculation

Authors' calculation

Authors' calculation

Authors' calculation

Authors' calculation

Authors' calculation

Authors' calculation

Authors' calculation

Authors' calculation

Authors' calculation

Authors' calculation

Authors' calculation

Authors' calculation

Authors' calculation

Authors' calculation

Authors' calculation

Authors' calculation

Authors' calculation

Authors' calculation

Authors' calculation

Authors' calculation

Authors' calculation

The table defines the variables used in the study and the source of the data. 
Appendix 2 Correlation matrix

\begin{tabular}{|c|c|c|c|c|c|c|c|c|c|c|c|c|c|c|c|c|}
\hline & $\begin{array}{c}\text { DBOARD } \\
\text { TYPE }\end{array}$ & $\begin{array}{c}\text { LNBOAR } \\
\text { DSIZE }\end{array}$ & $\begin{array}{c}\text { LNBOAR } \\
\text { DTEN }\end{array}$ & $\begin{array}{c}\angle N B O A R \\
D A G E\end{array}$ & $\begin{array}{c}\text { BOARDD } \\
\text { IVX }\end{array}$ & $\begin{array}{c}\text { BOARDW } \\
\text { OM2 }\end{array}$ & $\begin{array}{c}\text { BOARDE } \\
\text { MPL2 }\end{array}$ & $\begin{array}{l}\text { BOARDN } \\
\text { ATMIX } 2\end{array}$ & $\begin{array}{c}C V B O A R \\
D A G E\end{array}$ & LNTA & $T A G A$ & LOANTA & $T D T A$ & ETA & $\begin{array}{c}\text { LLPLOA } \\
N\end{array}$ & $C I$ \\
\hline DBOARDTYPE & 1 & & & & & & & & & & & & & & & \\
\hline LNBOARDSIZE & $\begin{array}{c}0.2271 * \\
0\end{array}$ & 1 & & & & & & & & & & & & & & \\
\hline LNBOARDTEN & $\begin{array}{l}0.0288 \\
0.4963\end{array}$ & $\begin{array}{c}0.0751^{*} \\
0.0757\end{array}$ & 1 & & & & & & & & & & & & & \\
\hline LNBOARDAGE & $\begin{array}{c}0.1486^{*} \\
0.0004\end{array}$ & $\begin{array}{c}0.2173^{*} \\
0\end{array}$ & $\begin{array}{c}0.3560 * \\
0\end{array}$ & 1 & & & & & & & & & & & & \\
\hline BOARDDIVX & $\begin{array}{c}-0.1168 * \\
0.0055\end{array}$ & $\begin{array}{c}0.1566^{*} \\
0.0002\end{array}$ & $\begin{array}{l}0.0472 \\
0.2648\end{array}$ & $\begin{array}{c}-0.2689 * \\
0\end{array}$ & 1 & & & & & & & & & & & \\
\hline BOARDWOM 2 & $\begin{array}{c}-0.2915^{*} \\
0\end{array}$ & $\begin{array}{c}-0.0757 * \\
0.0727\end{array}$ & $\begin{array}{l}0.0188 \\
0.6572\end{array}$ & $\begin{array}{c}-0.1338^{*} \\
0.0015\end{array}$ & $\begin{array}{c}0.6161 * \\
0\end{array}$ & 1 & & & & & & & & & & \\
\hline BOARDEMPL2 & $\begin{array}{c}-0.1985^{*} \\
0\end{array}$ & $\begin{array}{c}0.2020^{*} \\
0\end{array}$ & $\begin{array}{c}0.1323^{*} \\
0.0017\end{array}$ & $\begin{array}{c}-0.2337 * \\
0\end{array}$ & $\begin{array}{c}0.6568 * \\
0\end{array}$ & $\begin{array}{c}0.3225^{*} \\
0\end{array}$ & 1 & & & & & & & & & \\
\hline BOARDNATMIX2 & $\begin{array}{c}-0.0021 \\
0.9614\end{array}$ & $\begin{array}{c}0.0740^{*} \\
0.0856\end{array}$ & $\begin{array}{c}-0.0836^{*} \\
0.0527\end{array}$ & $\begin{array}{c}-0.1164 * \\
0.0068\end{array}$ & $\begin{array}{c}0.5356^{*} \\
0\end{array}$ & $\begin{array}{c}0.2001 * \\
0\end{array}$ & $\begin{array}{c}0.0729 * \\
0.0907\end{array}$ & 1 & & & & & & & & \\
\hline CVBOARDAGE & $\begin{array}{c}0.0093 \\
0.826\end{array}$ & $\begin{array}{l}0.0061 \\
0.8855\end{array}$ & $\begin{array}{c}-0.0074 \\
0.8615\end{array}$ & $\begin{array}{c}-0.2720^{*} \\
0\end{array}$ & $\begin{array}{c}0.2513 * \\
0\end{array}$ & $\begin{array}{c}-0.1043^{*} \\
0.0132\end{array}$ & $\begin{array}{l}0.0188 \\
0.6569\end{array}$ & $\begin{array}{c}-0.0583 \\
0.1761\end{array}$ & 1 & & & & & & & \\
\hline LNTA & $\begin{array}{l}-0.0255 \\
0.5452\end{array}$ & $\begin{array}{c}0.3924 * \\
0\end{array}$ & $\begin{array}{c}-0.0946 * \\
0.025\end{array}$ & $\begin{array}{c}0.2520^{*} \\
0\end{array}$ & $\begin{array}{c}0.1490 * \\
0.0004\end{array}$ & $\begin{array}{c}0.3011 * \\
0\end{array}$ & $\begin{array}{l}0.0626 \\
0.1378\end{array}$ & $\begin{array}{c}0.1437 * \\
0.0008\end{array}$ & $\begin{array}{c}-0.2491 * \\
0\end{array}$ & 1 & & & & & & \\
\hline TAGA & $\begin{array}{c}-0.0029 \\
0.9452\end{array}$ & $\begin{array}{c}-0.1460 * \\
0.0005\end{array}$ & $\begin{array}{l}0.0279 \\
0.5092\end{array}$ & $\begin{array}{c}-0.1112 * \\
0.0083\end{array}$ & $\begin{array}{c}-0.0528 \\
0.2113\end{array}$ & $\begin{array}{c}-0.0585 \\
0.1659\end{array}$ & $\begin{array}{c}-0.0755^{*} \\
0.0735\end{array}$ & $\begin{array}{c}-0.0173 \\
0.689\end{array}$ & $\begin{array}{l}0.0536 \\
0.2043\end{array}$ & $\begin{array}{c}-0.2012^{*} \\
0\end{array}$ & 1 & & & & & \\
\hline LOANTA & $\begin{array}{l}0.0146 \\
0.7293\end{array}$ & $\begin{array}{c}0.1443 * \\
0.0006\end{array}$ & $\begin{array}{c}0.1615^{*} \\
0.0001\end{array}$ & $\begin{array}{c}0.2341 * \\
0\end{array}$ & $\begin{array}{c}-0.1955^{*} \\
0\end{array}$ & $\begin{array}{c}-0.1712 * \\
0\end{array}$ & $\begin{array}{c}-0.2125^{*} \\
0\end{array}$ & $\begin{array}{c}-0.0977 * \\
0.0232\end{array}$ & $\begin{array}{c}0.0911^{*} \\
0.0307\end{array}$ & $\begin{array}{c}-0.1609 * \\
0.0001\end{array}$ & $\begin{array}{l}-0.043 \\
0.3082\end{array}$ & 1 & & & & \\
\hline$T D T A$ & $\begin{array}{l}0.0601 \\
0.1544\end{array}$ & $\begin{array}{c}-0.1578 * \\
0.0002\end{array}$ & $\begin{array}{c}0.1052 * \\
0.0127\end{array}$ & $\begin{array}{c}-0.1798 * \\
0\end{array}$ & $\begin{array}{c}-0.1565^{*} \\
0.0002\end{array}$ & $\begin{array}{c}-0.3079 * \\
0\end{array}$ & $\begin{array}{c}-0.0159 \\
0.7059\end{array}$ & $\begin{array}{c}-0.1365^{*} \\
0.0015\end{array}$ & $\begin{array}{c}0.1297 * \\
0.002\end{array}$ & $\begin{array}{c}-0.5979 * \\
0\end{array}$ & $\begin{array}{l}0.0465 \\
0.2705\end{array}$ & $\begin{array}{c}0.3350 * \\
0\end{array}$ & 1 & & & \\
\hline ETA & $\begin{array}{l}0.0268 \\
0.5253\end{array}$ & $\begin{array}{c}-0.1149^{*} \\
0.0063\end{array}$ & $\begin{array}{l}0.0283 \\
0.5041\end{array}$ & $\begin{array}{c}-0.0312 \\
0.4602\end{array}$ & $\begin{array}{c}-0.1224 * \\
0.0036\end{array}$ & $\begin{array}{c}-0.2073 * \\
0\end{array}$ & $\begin{array}{c}-0.1527 * \\
0.0003\end{array}$ & $\begin{array}{c}0.1110^{*} \\
0.0099\end{array}$ & $\begin{array}{c}0.1099 * \\
0.009\end{array}$ & $\begin{array}{c}-0.5105^{*} \\
0\end{array}$ & $\begin{array}{c}0.0985^{*} \\
0.0194\end{array}$ & $\begin{array}{c}0.2136^{*} \\
0\end{array}$ & $\begin{array}{c}0.3694 * \\
0\end{array}$ & 1 & & \\
\hline LLPLOAN & $\begin{array}{c}0.0932 * \\
0.0285\end{array}$ & $\begin{array}{c}-0.1363 * \\
0.0013\end{array}$ & $\begin{array}{c}-0.0972 * \\
0.0227\end{array}$ & $\begin{array}{c}0.1403 * \\
0.0009\end{array}$ & $\begin{array}{c}-0.2014 * \\
0\end{array}$ & $\begin{array}{c}-0.1116^{*} \\
0.0087\end{array}$ & $\begin{array}{c}-0.2058 * \\
0\end{array}$ & $\begin{array}{c}-0.1220 * \\
0.0049\end{array}$ & $\begin{array}{l}0.0016 \\
0.9703\end{array}$ & $\begin{array}{c}-0.1111 * \\
0.009\end{array}$ & $\begin{array}{c}-0.1500 * \\
0.0004\end{array}$ & $\begin{array}{c}0.2814 * \\
0\end{array}$ & $\begin{array}{c}0.2807 * \\
0\end{array}$ & $\begin{array}{l}0.0285 \\
0.5046\end{array}$ & 1 & \\
\hline$C I$ & $\begin{array}{c}0.0963 * \\
0.0228\end{array}$ & $\begin{array}{l}0.0618 \\
0.1443\end{array}$ & $\begin{array}{c}-0.2642 * \\
0\end{array}$ & $\begin{array}{l}0.0081 \\
0.8491\end{array}$ & $\begin{array}{c}-0.0306 \\
0.4709\end{array}$ & $\begin{array}{c}-0.0471 \\
0.2665\end{array}$ & $\begin{array}{c}0.0765^{*} \\
0.0707\end{array}$ & $\begin{array}{c}-0.1534 * \\
0.0004\end{array}$ & $\begin{array}{l}0.0185 \\
0.6619\end{array}$ & $\begin{array}{c}0.1379 * \\
0.0011\end{array}$ & $\begin{array}{c}-0.1485^{*} \\
0.0004\end{array}$ & $\begin{array}{c}-0.2802 * \\
0\end{array}$ & $\begin{array}{c}-0.2007 * \\
0\end{array}$ & $\begin{array}{c}-0.2848 * \\
0\end{array}$ & $\begin{array}{l}0.0275 \\
0.5201\end{array}$ & 1 \\
\hline
\end{tabular}

The table reports correlations for the regressors used the analysis. * indicates significant at 10 per cent level. Definitions of the variables are provided in Appendix 1. 
Appendix 3 Sample composition by country in 2014

\begin{tabular}{lcc}
\hline Country & Number of banks & Total asset in 2014 (Euro millions) \\
\hline Austria & 5 & 352,100 \\
Belgium & 3 & 591,467 \\
Cyprus & 2 & 39,788 \\
Czech Republic & 1 & 31,296 \\
Germany & 4 & $2,850,389$ \\
Denmark & 5 & 534,706 \\
Spain & 6 & $2,567,366$ \\
France & 5 & $5,539,100$ \\
Greece & 4 & 301,115 \\
Hungary & 1 & 34,694 \\
Ireland & 2 & 270,500 \\
Italy & 13 & $2,361,156$ \\
Lithuania & 1 & 852 \\
Malta & 1 & 7,049 \\
Netherlands & 1 & 2,998 \\
Poland & 6 & 147,277 \\
Portugal & 4 & 231,986 \\
Romania & 1 & 11,036 \\
Sweden & 5 & $1,452,367$ \\
United Kingdom & 7 & $6,987,164$ \\
Total & 77 & $24,314,406$ \\
\hline The
\end{tabular}

The table shows the number of banks in the sample by country and their size in 2014. 


\section{References}

Adams, R. B. and Ferreira, D. (2007) A Theory of Friendly Boards, Journal of Finance 62(1), 217 - 250.

Adams, R. B. and Ferreira, D. (2009) Women in the boardroom and their impact on governance and performance, Journal of Financial Economics 94, 291-309.

Adams, R. B. and Ferreira, D. (2012) Regulatory Pressure and Bank Directors' Incentives to Attend Board Meetings, International Review of Finance, 12(2), 227-248

Adams, R.B. and Funk, P. (2012) Beyond the glass ceiling: Does gender matter?, Management Science $58,219-235$

Adams, R. B., Hermalin, B. and Weisbach, M. (2010) The Role of Boards of Directors in Corporate Governance: A Conceptual Framework and Survey, Journal of Economic Literature 48(1): 58-107.

Adams, R. B. and Mehran, H. (2003) Is corporate governance different for bank holding companies?, Economic Policy Review, Federal Reserve Bank of New York, issue Apr, 123-142.

Adams, R. B. and Mehran, H. (2012) Bank Board Structure, and Performance: Evidence for large bank holding companies, Journal of Financial Intermediation 21, 243-267.

Ahern K.R. and Dittmar, A.K. (2012) The changing of the boards: the impact on firm valuation of mandated female board representation, Quarterly Journal of Economics, 1-60.

Adams R.B., and Santos J.A.C. (2006) Identifying the effect of managerial controlon firm performance, Journal of Accounting and Economics 41, 55-85.

Andrés P. and Vallelado, E. (2008) Corporate governance in banking: The role of the board of directors, Journal of Banking and Finance 32, 2570-2580.

Anginer, D., Demirgüç-Kunt, A., Huizinga, H. and Ma, K. (2017) Corporate governance of banks and financial stability, Journal of Financial Economics, ISSN 0304-405X (In Press).

Arellano, M. and Bond, S. (1991) Some tests of specification for panel data: Monte Carlo evidence and an application to employment equations, Review of Economic Studies 58, 277-97.

Arellano, M., and Bover, O. (1995) Another look at the instrumental variable estimation of errorcomponents models, Journal of Econometrics 68, 29-51.

Beltratti A. and Stulz, R. M. (2012) The credit crisis around the globe: Why did some banks perform better?, Journal of Financial Economics 105(1), 1-17.

Bennouri, M., Chtiouib, T., Nagati, H., and Nekhili, M. (2018) Female board directorship and firm performance: What really matters? Journal of Banking and Finance 88, 267-291.

Berger A. N., Kick T., and Schaeck K., (2014) Executive board composition and bank risk taking, Journal of Corporate Finance 28, 48-65.

Blau, P. M. (1977). Inequality and Heterogeneity. Glencoe, IL: Free Press. 
Blundell, R. and Bond, S. (1998) Initial conditions and moment restrictions in dynamic panel data models, Journal of Econometrics 87, 115-143.

Boone A.L., Casares Field L., Karpoff J.M., and Raheja C.G. (2007) The determinants of corporate board size and composition: an empirical analysis, Journal of Financial Economics 85, 66-101.

Carter, D.A., D'Souza, F.P, Simkins, B.J., and Simpson, W.G. (2010) The Gender and Ethnic Diversity of US Boards and Board Committees and Firm Financial Performance, Corporate Governance 18(5), 396 $-414$.

Carter, D.A., Simkins, B.J., and Simpson, W.G. (2003) Corporate Governance, Board Diversity and Firm Value, Financial Review 38, 33-53.

Chakrabarty S. (2009) The influence of national culture and institutional voids on family ownership of large firms: A country level empirical study, Journal of International Management 15(1), 32-45.

Celikyurt, U., Sevilir, M., and Shivdasani, A. (2014) Venture Capitalists on Boards of Mature Public Firms, The Review of Financial Studies, 27(1), 56-101.

Cheng S. (2008) Board size and the variability of corporate performance, Journal of Financial Economics $87,157-176$.

Coles J.L., Daniel N.D., and Naveen L. (2008) Boards: does one size fit all?, Journal of Financial Economics 87, 329-356.

Conyon, M.J., and Peck, S.I. (1998) Board size and corporate performance: evidence from European countries, The European Journal of Finance 4(3), 291-304.

De Andres P., and Vallelado E. (2008) Corporate governance in banking: The role of the board of directors, Journal of Banking and Finance, 32(12), 2570-2580

Dezso, C.L. and Ross D.G. (2011) Does Female Representation in Top Management Improve Firm Performance? A Panel Data Investigation, Robert H. Smith School Research Paper (RHS) 06-104.

Eisenberg, T., S. Sundgren and Wells, M. (1998) Larger Board Size and Decreasing Firm Value in Small Firms, Journal of Financial Economics 48, 35-54.

European Banking Authority (2011) Guidelines on Internal Governance, September, London, available at https://www.eba.europa.eu/documents/10180/103861/EBA-BS-2011-116-final-EBA-Guidelines-onInternal-Governance-\%282\%29_1.pdf

European Banking Authority, and European Securities and Markets Authority (2017) Joint ESMA and EBA Guidelines on the assessment of the suitability of members of the management body and key function holders under Directive 2013/36/EU and Directive 2014/65/EU, September, available at https://www.eba.europa.eu/documents/10180/1972984/Joint+ESMA+and+EBA+Guidelines+on+the+ass essment+of+suitability+of+members+of+the+management+body+and+key+function+holders+\%28EBAGL-2017-12\%29.pdf 
European Commission (2010) Corporate Governance in Financial Institutions and Remuneration Policies.

Green

Paper

available

at

http://ec.europa.eu/internal_market/company/modern/corporate_governance_in_financial_institutions_en. htm

Fahlenbrach R., Low A. and Stulz R. (2017) Do independent director departures predict future bad events?, Review of Financial Studies 30(7), 2313-2358.

Faleye, O., Hoitash R., and Hoitash U. (2011) The costs of intense board monitoring, Journal of Financial Economics 101, 160-181.

Farag H., and Mallin C. (2017) Board diversity and financial fragility: evidence from European banks, International Review of Financial Analysis 49, 98-112.

Fields, M., and Keys, P., (2003) The emergence of corporate governance from Wall St. to Main St.: outside directors, board diversity, earnings management, and managerial incentives to bear risk, Financial Review 38, 1-24.

Garcia-Meca E., Garcia-Sanchez I-M., and Martinez-Ferrero J. (2015) Board diversity and its effects on bank performance: An international analysis, Journal of Banking and Finance 53, 202-214.

Garcia-Lara J. M., Penalva- Zuasti J., and Scapin M. P. (2017) Accounting quality effects of imposing quotas on boards of directors, unpublished.

Hagendorff, J., and Keasey, K., (2012) The value of board diversity in banking: evidence from the market for corporate control, The European Journal of Finance 18(1), 41-58.

Hansen, P., and Singleton, K. (1982) Generalized Instrumental Variable Estimation of Nonlinear Rational Expectations Models, Econometrica 50(5), 1269-1286.

Harris M. and Raviv, A. (2008) A theory of board control and size, Review of Financial Studies 21(4), 1797-1832.

Hatzimihail N. (2013) Cyprus as a Mixed Legal System, Journal of Civil Law Studies 6(1), 37-96

Hermalin, B E., and Weisbach, M. (2003) Boards of directors as an endogenously determined institution: A survey of the economic literature, Economic Policy Review 9, 7-26.

Hofstede, G. (1983) The cultural relativity of organizational practices and theories, Journal of International Business Studies 14, 75-89.

Hofstede, G., Hofstede, G.J., and Minkov, M. (2010) Cultures and organizations: Software of the mind, McGraw-Hill Education, $3^{\text {rd }}$ edition.

Huang, S., and Hilary, G. (2017) Zombie Board: Board Tenure and Firm Performance. 1-78. Research Collection School of Accountancy. http://ink.library.smu.edu.sg/soa_research/1329 
Huyghebaert, N., and Wang, L. (2017) Value creation and value distribution in Chinese listed firms: the role of ownership structure, board characteristics, and control, The European Journal of Finance, DOI: 10.1080/1351847X.2017.1386704

Jensen, M., (1993) The modern industrial revolution, exit, and the failure of internal control systems, Journal of Finance, 48, 831 -880.

Kanagaretnam, K., Lim, C. Y. and Lobo, G. J. (2011) Effects of national culture on earnings management in banks, Journal of International Business Studies 42(6), 853-874.

Kanagaretnam, K., Lim, C.Y., and Lobo, G.J. (2014) Influence of National Culture on Accounting Conservatism and Risk-Taking in the Banking Industry, The Accounting Review 89(3), 1115-1149.

Kauko, K. (2009) Managers and efficiency in banking, Journal of Banking and Finance 33, 546-556.

King, T., Srivastav, A., and Williams J. (2016) What's in an education? Implications of CEO education for bank performance, Journal of Corporate Finance 37, 287-308.

Laeven L., and Levine, R. (2009) Bank governance, regulation and risk taking, Journal of Financial Economics 93, 259-275.

Li N. and Wahid, A.S. (2017) Director Tenure Diversity and Board Monitoring Effectiveness, Contemporary Accounting Research, doi: 10.1111/1911-3846.12332

Linck J.S., Netter J.M., and Yang T. (2008) The determinants of board structure, Journal of Financial Economics 87, 308-328.

Mateos de Cabo R., Gimeno R., and Nieto M.J. (2012) Gender diversity on European banks' boards of directors, Journal of Business Ethics 109(2), 145-162.

Mehran H., Morrison A. and Shapiro J. (2011) Corporate Governance and banks: what have we learned from the financial crisis?, Federal Reserve Bank of New York, Staff Report 502, June.

Newburry W., and Yakova N. (2006) Standardization preferences: A function of national culture work interdependence and local embeddedness, Journal of International Business Studies 37, 44-60.

Oxelheim L., Gregoric A., Rabdoy T., and Thomsen S. (2013) On the internationalization of corporate boards: The case of Noridc firms, Journal of International Business Studies 44, 173-194.

Shleifer A. and Vishny, R.W. (1997) A Survey of Corporate Governance, Journal of Finance 52(2), 737783.

SEC (2010) Proxy Disclosure Enhancements, Final Rule, 28 February, available at: https://www.sec.gov/rules/final/2009/33-9089.pdf

Sila V., Gonzalez A., and Hagendorff J. (2016) Women on board: Does boardroom gender diversity affect firm risk?, Journal of Corporate Finance 36, 26-53.

Terjesen, S. and Singh, V. (2008). Female presence on corporate boards: A multi-country study of environmental context, Journal of Business Ethics 83, 55-63. 
Terjesen S., Couto E.B., and Francisco, P.M., (2016) Does the presence of independent and female directors impact firm performance? A multi-country study of board diversity, Journal of Management and Governance 20(3), 447-483.

Westphal, J.D., and Zajac. E.J. (1995) Who shall govern? CEO/board power, demographic similarity, and new director selection, Administrative Science Quarterly 40, 60-83.

Windmeijer, F. (2005) A finite sample correction for the variance of linear efficient two-step GMM estimators, Journal of Econometrics 126, 25-51. 